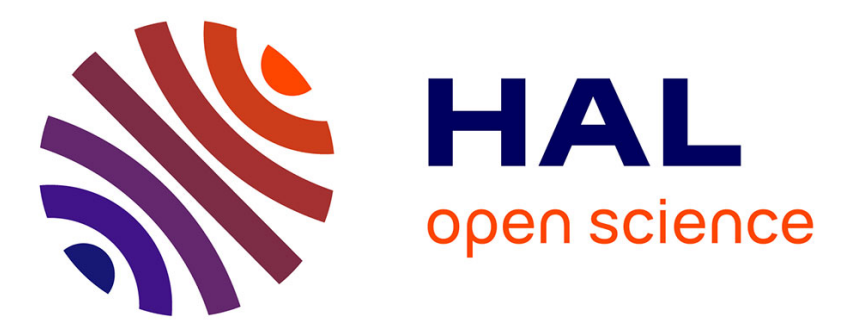

\title{
Geometry of flexural uplift by continental rifting in Corinth, Greece
}

David Fernández-blanco, Gino Gelder, Robin Lacassin, Rolando Armijo

\section{To cite this version:}

David Fernández-blanco, Gino Gelder, Robin Lacassin, Rolando Armijo. Geometry of flexural uplift by continental rifting in Corinth, Greece. Tectonics, 2019, 10.1029/2019TC005685 . insu-02362436

\section{HAL Id: insu-02362436 \\ https://hal-insu.archives-ouvertes.fr/insu-02362436}

Submitted on 1 Jul 2020

HAL is a multi-disciplinary open access archive for the deposit and dissemination of scientific research documents, whether they are published or not. The documents may come from teaching and research institutions in France or abroad, or from public or private research centers.
L'archive ouverte pluridisciplinaire $\mathbf{H A L}$, est destinée au dépôt et à la diffusion de documents scientifiques de niveau recherche, publiés ou non, émanant des établissements d'enseignement et de recherche français ou étrangers, des laboratoires publics ou privés. 


\section{Tectonics}

\section{RESEARCH ARTICLE \\ 10.1029/2019TC005685}

Key Points:

- Corinth Rift uplifting landscape characterises flexure geometry at its spatiotemporal scale in nature (tens of $\mathrm{km} ; 10^{4}-10^{6} \mathrm{yr}$ )

- Continental lithosphere coherently up-bends across rift (>50 km) and parabolically decay along rift $(>60$ $\mathrm{km})$ throughout faulting $\left(\sim 10^{6} \mathrm{yr}\right)$

- Corinth Rift unparalleled record of flexural uplift and highly-localized strain suggest these processes typify early continental rifting

Supporting Information:

- Supporting Information S1

Correspondence to: D. Fernández-Blanco, geo.david.fernandez@gmail.com

Citation:

Fernández-Blanco, D., de Gelder, G., Lacassin, R., \& Armijo, R. (2020). Geometry of flexural uplift by continental rifting in Corinth, Greece. Tectonics, 39, e2019TC005685. https:// doi.org/10.1029/2019TC005685

Received 21 MAY 2019 Accepted 20 OCT 2019 Accepted article online 8 NOV 2019

2019. American Geophysical Union. All Rights Reserved.

\section{Geometry of Flexural Uplift by Continental Rifting in Corinth, Greece}

\author{
David Fernández-Blanco $^{1}$ (D), Gino de Gelder ${ }^{1}$ (D), Robin Lacassin ${ }^{1}$ iD, and Rolando Armijo ${ }^{1}$ (iD \\ ${ }^{1}$ Institut de Physique du Globe de Paris, CNRS, Université de Paris, Paris, France
}

\begin{abstract}
Understanding early rifting of continental lithosphere requires accurate descriptions of up-bended rift margins and footwalls that ought to correlate in space and time with the elastic flexural uplift that produces them. Here we characterize the geometry of elastic flexural uplift by continental rifting at its spatiotemporal scale in nature (tens of kilometers; $10^{4}-10^{6}$ years) using geomorphic evidence along the uplifting margin of the Corinth Rift, Greece. Our geomorphic analyses of space-borne topography novelly outline the coherent elastic flexure of continental lithosphere along and across the rift margin and throughout faulting ( $10^{6}$ years), as defined by the distribution of footwall uplift south of the active bounding fault. Topography and river drainages outline an elastic flexure signal that increases exponentially toward the bounding fault across the footwall for $>50 \mathrm{~km}$ and changes in amplitude along the footwall following a parabola that decays from the rift center and has a $>60-\mathrm{km}$ wavelength that correlates with rift length. This continental lithosphere up-bend correlates with the scale of the rift, and appears maximum in the center of the rift, where drainage reversal of large catchments suggests rapid slip rates at the bounding fault. This is consistent with the growth of a new, rift-scale, high-angle normal fault. The coherency of elastic flexure in space and time implies highly localized strain in the rift-bounding fault and suggests that the fault transects continental lithosphere with long-term strength. The unparalleled record of flexural uplift and highly localized strain in the landscape of Corinth suggest these processes are intrinsic to early continental rifting elsewhere.
\end{abstract}

\section{Introduction}

Numerical models show that crustal-scale elastic flexure and localized strain occur in the flanks of highangle normal faults transecting continental lithosphere (e.g., Buck, 1993; King \& Ellis, 1990). Elastic flexure leads to fault flank uplift and subsidence that span tens of kilometers along strike and decay exponentially across strike within few tens of kilometers (Figure 1a; King \& Ellis, 1990; Weissel \& Karner, 1989). Similar flexural strain, albeit of much smaller amplitude, occurs in high-angle faults during $M_{w} \geq 6$ earthquakes, suggesting that cumulative seismic events may result in kilometer-scale longterm flexural relief (King et al., 1988). By contrast, low-angle faults develop little to no elastic flexure (Figure 1b; e.g., Forsyth, 1992). Up-warping in continental rift margins and footwalls is particularly interesting, for the upflexed topography can be used to discriminate between low- and high-angle extensional faulting (Bell et al., 2017). Similarly, the wavelength and curvature of flexural uplift can be used to infer relative strength layering of the underlying lithosphere (e.g., Armijo et al., 1996; De Gelder et al., 2019). These and other inferences on lithosphere strain, mechanics, and rheology are nevertheless limited to the spatiotemporal scale and overall detail at which flexure is characterized in nature.

Lithospheric elastic flexure in extensionally uplifted rift margins and footwalls produces shortwavelength tilts that sporadically steer drainage reversals in large Cenozoic continental rifts, such as the East African and Baikal rifts, and in individual grabens within wider areas of diffuse extension, such as the Basin and Range and Tibet (e.g., Armijo et al., 1986; Doornkamp \& Temple, 1966; Petit \& Ebinger, 2000; Stewart, 1978). Research in these areas uses flexure geometries derived from relatively imprecise observations of topography to deduce rift mechanics and/or geodynamics (e.g., Brown \& Phillips, 1999; Masek et al., 1994; Owens, 1983; ter Voorde et al., 1998; Zandt \& Owens, 1980). Finer characterizations of flexure geometry that may lead to better-constrained results are either precluded by scant unambiguous geomorphological evidence in relatively old ( $>10^{6}$ years) regions (e.g., Stein et al., 1988) or restricted to individual transects (Armijo et al., 1996; De Gelder et al., 2019) and/or short temporal scales $\left(<10^{3}\right.$ years; e.g., Thompson \& Parsons, 2016). 
This paper aims at defining the flexural uplift geometry during continental rifting at its spatial and temporal scale in nature (tens of kilometers along and across fault strike, and $10^{4}-10^{6}$ years). We use digital elevation data to explore the existence, geometry, coherency, and extent of flexure in the southern, uplifting margin of the rapidly-extending Corinth Rift, in central Greece. We resolve the across- and along-strike components of flexural uplift, analyzing footwall topography and river catchments collectively by means of conventional and new morphotectonic approaches that highlight the relationships between footwall landscape and active fault. Topography, rivers, and morphometric proxies throughout the rift margin novelly portray elastic flexural uplift, highly localized strain and large lithospheric strength coherently sustained in space $(>50 \mathrm{~km}$ across and along rift margin) and time ( $10^{6}$ years). Given that the record of early continental rifting in the Corinth Rift is globally unique, we infer that elastic flexure and high strain localization are intrinsic processes of early continental rifting. This inference implies that elastic flexure and high strain localization may have occurred in continental rifts and extensional footwalls of any age or extension rate, even without clear evidence of these processes.

\section{Corinth Rift: Early Continental Rifting Natural Laboratory}

The amagmatic continental rift of Corinth is at a very early rifting stage in relation to its current riftbounding fault system (Main fault system; Figure 2), after a period of distributed extension and faulting, (Bell et al., 2017; Fernández-Blanco et al., 2019). Rollback of the African slab and southward retreat of the Hellenic trench since 30-45 Ma (e.g., Brun \& Sokoutis, 2010; Jolivet et al., 2013; Jolivet \& Brun, 2010; Le Pichon \& Angelier, 1981) caused distributed extension, basinward fault migration and block tilting that started in the area at 4-5 Ma (e.g., Doutsos \& Piper, 1990; Gawthorpe et al., 1994; Goldsworthy \& Jackson, 2001). At 1 Ma or younger times, activity along the north-dipping high-angle fault system that currently bounds the rift southern margin (Main fault system; Figure 2; e.g., Armijo et al., 1996; Fernández-Blanco et al., 2019; Nixon et al., 2016) led to a rapid increase in tectonic rates and ensued a prominent elastic flexure that has been characterized in detail in the east of the rift (Figure 3; Armijo et al., 1996; De Gelder et al., 2019). The Main fault system accommodates faster geodetic strain rates ( 1-1.5 cm/year; Avallone et al., 2004) than any subaerially exposed normal fault on Earth (Charalampakis et al., 2014; Tetreault \& Buiter, 2018) and has a remarkable seismic activity (e.g., Bernard et al., 2006). Rapid Quaternary coastal uplift suggests fast localization of extension in relation with this fault system (Roberts et al., 2009), which probably has larger uplift at the rift center (e.g., Dufaure, 1975; Pirazzoli et al., 2004). Footwall uplift rates of $\sim 1 \mathrm{~mm} /$ year for the last $330 \mathrm{kyr}$ notably exceed regional uplift rates of $\sim 0-0.3 \mathrm{~mm} /$ year (e.g., Armijo et al., 1996; McNeill \& Collier, 2004; Turner et al., 2010) and set, atop inherited relief (e.g., Ghisetti \& Vezzani, 2005; Hemelsdaël et al., 2017; Ori, 1989), the modern rift asymmetry. Given the above, the southern, uplifting margin of the Corinth Rift is an exceptional site to constrain the geometry of flexure (Figures 2 and 3).

a

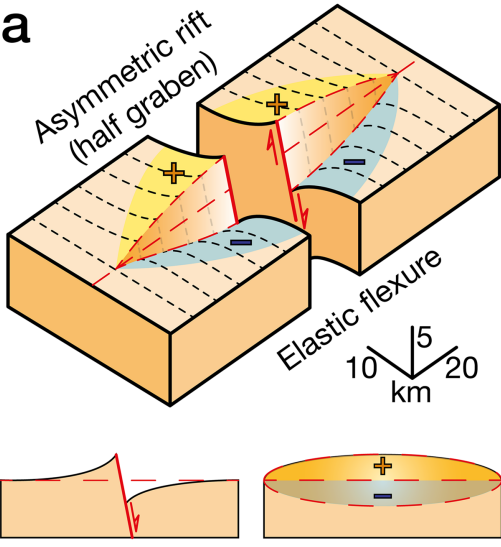

b

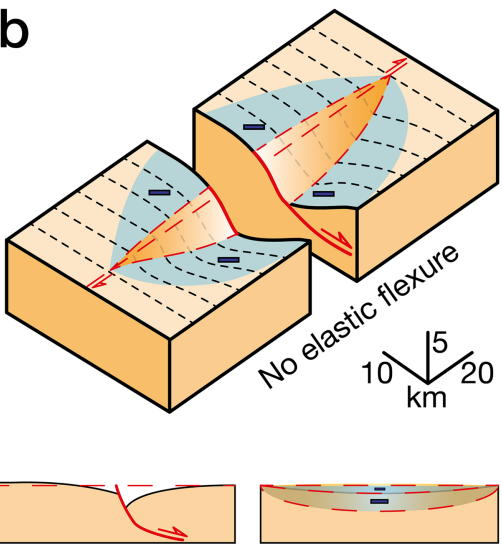

Figure 1. Block diagrams of vertical motions led by high- and low-angle normal faults. (a) Block diagram with flexural footwall uplift and flexural hanging-wall subsidence expected in relation to a high-angle planar normal fault. (b) Block diagram with footwall and hanging-wall subsidence expected in relation to a low-angle detachment normal fault. Across (left) and along (right) fault strike views are shown below each case. 


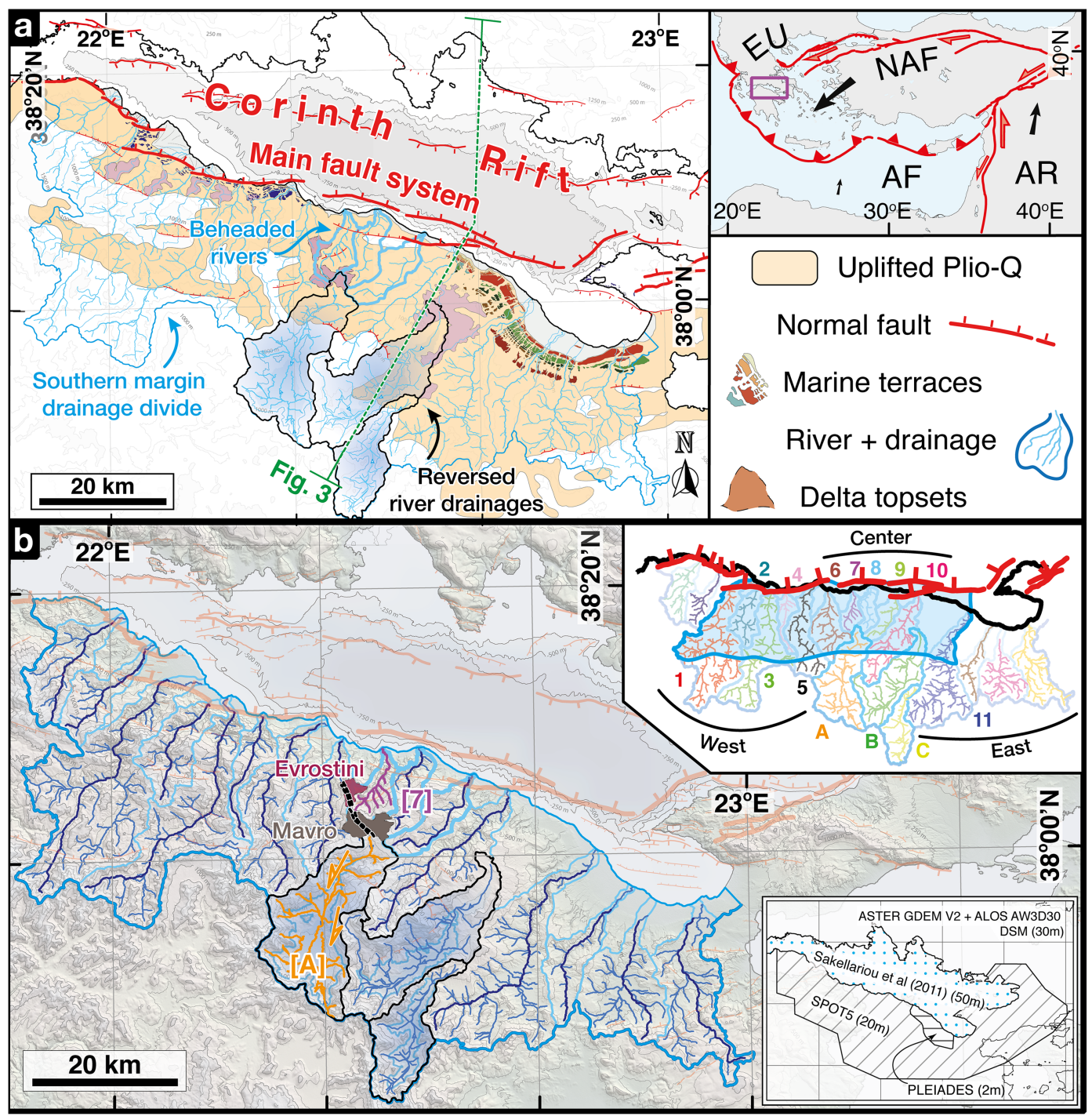

Figure 2. Corinth Rift map. (a) Simplified map of the southern margin of the Corinth Rift highlighting geomorphological and geological features associated with the Main fault system, which is shown in red. Drainage basins are shown in blue, the uplifted Plio-Q basin infill in yellow, uplifted marine terraces and perched Gilbert-type deltas are in several colors and in light purple, respectively. The map also shows the location of the onshore and offshore cross section in Figure 3. The top right inset shows the general tectonic framework of the rift, with the acronyms of EU, AF, and AR that stand for Eurasian, African, and Arabian tectonic plates, respectively, and NAF for North Anatolian Fault. (b) Topography, river drainages, and river networks in the southern rift margin. River drainages are in blue, with their river networks in darker blue, and their trunks in marine blue. Watersheds of steep and short beheaded rivers are in thicker blue stroke, with the Dervenios River [7] in purple as representative for this group. Watersheds of endorheic drainages are in black stroke, with the Olvios River [A] in orange, as their reversed-flow representative. South tilted plains are shaded in blue. The map also shows the windgaps in Mavro and Evrostini Gilbert delta. The inset in the top right corner shows the indexing given to the rivers relevant to this study, with numbers for gulf-flowing rivers and letters for reversed rivers, now endorheic basins, and our division in the rift sectors of "East," "Center," and "West." This inset also shows the location of the polygon covering the footwall area used for the footwall relief calculation (see section 4.3). The inset in the bottom right shows the different sources of DEM data used for our composite DEM of the rift.

In the east rift, elastic flexure on the main fault flanks sets the modern asymmetry (Figure 3). An extensive sequence of exceptionally preserved marine terraces in the eastern footwall (Armijo et al., 1996), and prominent syntectonic sedimentary wedges of correlatable seismic horizons in its hanging-wall (Taylor et al., 2011) record an exponential increase in elastic flexure amplitude toward the rift bounding fault (Figure 3; De Gelder et al., 2019). Markers show the growth of $\sim 4.8 \mathrm{~km}$ of structural relief since the onset of bounding fault activity, 800-600 ka, which localized strain over a 300-kyr interval (Nixon et al., 2016). Flexural uplift on $10^{4}-10^{6}$-year time scales is recorded by the Late Pleistocene marine terraces (Figures 2 and 3; Armijo et al., 1996; De Gelder et al., 2019). If a similar signal of flexural uplift also exists westward, it should be recorded in geomorphological evidence along the rift margin. 


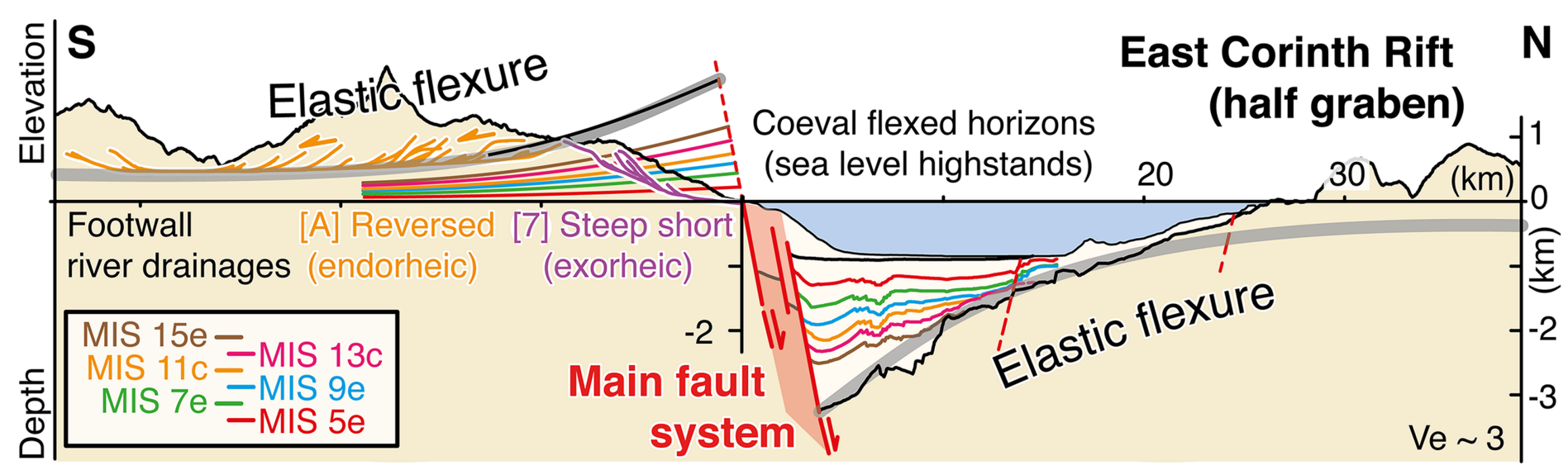

Figure 3. Onshore-offshore cross section across the eastern Corinth Rift. Onshore-offshore cross section showing elastic flexure as detailed by coeval markers of sea level and river profiles rescaled to fit the section located in Figure 2. Paleohorizons in different colors represent major sea level highstands (see inset in the bottom left) that have been derived from best fit quadratic curves of upflexed terraces in the onshore (De Gelder et al., 2019) and their tentatively correlatable seismic horizons in the offshore (Nixon et al., 2016) on the seismic line L35 of Taylor et al. (2011), depth-converted as in de Gelder et al. (2019). Modified after Figure 3 of de Gelder et al. (2019).

In the central rift, south-tilted Middle Pleistocene conglomerates of deltaic systems are carved by windgaps that bound formerly connected drainages (Dufaure, 1977). Steep and short beheaded catchments drain toward the gulf, northward of large, reversed drainages that now are at heights of 700-800 m and infill flat sedimentary plains with gentle south tilts (Figures 2 and 3; Seger \& Alexander, 1993). The uppermost abandoned valley is carved in the oldest delta (Mavro) and aligns with the windgap of a younger delta (Evrostini) located northwestward at lower elevations (Figure 2; e.g., Rohais et al., 2007). This implies that the same river bypassed the former delta to feed the latter delta. Such configuration of windgap-bounded drainages implies drainage reversals at large scale (e.g., Dufaure, 1977) and may result from footwall flexural uplift (Armijo et al., 1996). Being this the case, footwall flexural uplift would postdate Mavro Delta deposition and predate Evrostini Delta deposition, which chronostratigraphical and lithostratigraphical correlations set at $\sim 0.7 \mathrm{Ma}$ (Ford et al., 2016).

In the west rift, westward of the reversed drainages, the largest catchments have river morphologies that are similar albeit less marked, with steep gorges and narrow valleys in a broad upwarped zone that separates a low-gradient, low-relief landscape upstream from a steeper, high-relief landscape downstream (e.g., Seger \& Alexander, 1993; Zondervan et al., 2019). As in the rift center, west rift sequences of offlapping stranded deltas become younger coastward (Ford et al., 2012, 2016; Seger \& Alexander, 1993). This and former hanging-wall sediments uplifted by sequentially younger footwalls suggest basinward migration of border fault systems (e.g., Gawthorpe et al., 2017). No proposal of elastic flexure has been made to explain the evolution of the west rift sector, and no evidence of footwall flexural uplift has been documented.

\section{Working Framework and Hypotheses}

Given that the long-term slip and derived uplift patterns on bounding fault(s) control the long-term morphological evolution of rift margins and footwalls (e.g., Cowie \& Scholz, 1992), the landscape in these uplifted settings can be used to understand their controlling fault(s) (e.g., Cowie et al., 2006). High-angle normal faults have a predictable geometry of slip and slip rates along strike and uplift and uplift rates across strike. Along-strike, slip and slip rates parabolically decay from a maximum near the fault center to zero at fault tips (e.g., Bürgmann et al., 1994; Cowie \& Scholz, 1992; Dawers et al., 1993; Manighetti et al., 2001; Roberts \& Michetti, 2004). Such distribution of slip and slip rates controls the geometry and geomorphic evolution of along-footwall topography and river catchments (e.g., Densmore et al., 2004, 2005; Kent et al., 2016; RodaBoluda \& Whittaker, 2017). Across-strike, uplift and uplift rates exponentially decay from maxima near the fault to zero a few tens of kilometers away (e.g., King et al., 1988; King \& Ellis, 1990; Thompson \& Parsons, 2016). Such distribution of uplift and uplift rates control the geometry and geomorphic evolution 
of topography across the footwall (Armijo et al., 1996; De Gelder et al., 2019; Stein et al., 1988), but their effect on river catchments remains unexplored. The above implies that we can anticipate the morphological evolution for footwalls uplifting in relation to range-front high-angle normal faults (Armijo et al., 1986; Armijo et al., 1991; Wallace, 1978).

The geometry of topography flexed up toward the bounding fault has been often used to define the exponential increase in flexural uplift signal across extensional footwalls (e.g., Brown \& Phillips, 1999; Masek et al., 1994; Owens, 1983; Stein et al., 1988; ter Voorde et al., 1998; Zandt \& Owens, 1980) but the along-footwall signal of flexural uplift is still unlinked with the topography it shapes. Intuitively, the along-footwall shape of flexed topography should link with the displacement profile of the active fault. Similarly, the alongfootwall extent of flexed topography should correlate with fault length and its coherency should relate with the degree of strain localization at the fault.

River catchments are commonly used to resolve uplift signals and slip rates in extensional rift margins and footwalls (Boulton \& Whittaker, 2009; Gallen \& Wegmann, 2017; Kirby \& Whipple, 2012; Miller et al., 2012; Whittaker, 2012; Whittaker et al., 2008; Wobus et al., 2006). However, the influence of elastic flexure in the geometry and evolution of footwall rivers remains unexplored. This gap may result from the fact that morphometric analyses using drainage basin-scale metrics (Demoulin et al., 2015) are not suited for cases of flexure, for they average the spatially varying strike-perpendicular component of uplift across catchment. To our knowledge, only two studies consider flexure in rivers draining extensional footwalls. Goren et al. (2014) uses an expected flexural response to normal faulting in linear inversions that parametrize uplift spatial variability in the Inyo Range, California. Corti et al. (2018) studies the coupling between flexural uplift and fluvial erosion and its influence on rift (a)symmetry in the Main Ethiopian Rift, East Africa. These studies do not use the geometry of footwall rivers to infer the signal of flexural uplift. Thus, the influence of elastic flexure in the morphology and evolution of rivers draining extensional footwalls remains to be explored, and inversely, so does how the morphology of footwall rivers may inform on scale, geometry, and uplift patterns of the fault accommodating flexure.

In the Corinth Rift, well-established river catchments with their headwaters tens of kilometers south of the modern gulf shore flowed N-to-NE, draining inherited Hellenic paleotopography (Ford et al., 2012; Gawthorpe et al., 2017; Hemelsdaël \& Ford, 2016). Northward fault migration between $\sim 2.2$ and $\sim 1.8 \mathrm{Ma}$ resulted in rivers with northward flows that carried sediments uplifted in new footwalls toward their hanging-walls (e.g., Ford et al., 2016; Gawthorpe et al., 2017). Given that vertical offsets of antecedent faults were relatively small (Ford et al., 2012; Ori, 1989), and that $>1$ Ma passed before the onset of the current main border fault (Fernández-Blanco et al., 2019; Nixon et al., 2016), we consider that the antecedent river network was close to equilibrium, and thus that these rivers had graded longitudinal profiles.

Footwall rivers that drain orthogonally toward the range-front fault should experience the maximum gradient in flexural uplift. We expect that these rivers have transient longitudinal profiles that departure from their theoretical graded profiles. Such transient longitudinal profiles should have steep lower reaches adjusted to near-fault uplift, followed by anomalously low-gradient reaches immediately upstream, as flexural uplift decays exponentially across-footwall away from the fault. If this were the case, landward drainage tilts should be more prominent in the fault sectors that have larger uplift, and thus larger fault slip. Rift margin back-tilting would drive sediment starvation (Pechlivanidou et al., 2019), for acute drainage backtilts lower river erosion capabilities. Therefore, prominent flexural uplift may lead to an end-member case that forces drainage disruption in two sectors, a perched low-gradient river upstream, where flow is reversed, and a beheaded steep river downstream. Along-footwall, the heights of near-fault transitions from steep to gentler river reaches should also positively correlate with fault uplift and slip. The along-footwall continuity of the flexure signal should relate with the displacement profile of the associated fault and correlate with its length. Therefore, longitudinal profiles of successive rivers lying orthogonal to the fault can provide alongfootwall coverage and portray the lateral extent of flexure, provided that climatic and lithologic effects are relatively minor. This may in turn allow discriminating the effects of one or more faults.

\section{Methods and Assumptions}

We use digital elevation data with $20 \mathrm{~m}$ horizontal resolution to examine footwall topography, relief and river longitudinal profiles throughout the rift margin, as well as geomorphic proxies of uplift and uplift 
rate that we relate with displacement, slip, and slip rate on the bounding fault system. We analyzed footwall topography and river profiles in the rift margin sector where the bounding fault has a continuous length of $\sim 60 \mathrm{~km}$ along strike (Figure 2). This "main sector" includes 11 of the 16 largest rivers catchments draining north, almost orthogonally toward the master fault, and the 3 catchments with reversed drainage that now flow inland toward their former headwaters (Figure 2).

\subsection{Digital Elevation Models}

We used the 30-m horizontal resolution ALOS AW3D30 DSM (ALOS) and patched voids and gaps with ASTER GDEM v2 (ASTER) for an area inclusive of the whole Peloponnese and both margins of the Gulf of Corinth. We upsampled the merged digital elevation models (DEM) for latitudes north of Nafplion with a 20-m horizontal (post-spacing) resolution SPOT5 DEM of an area that covers the southern shoulder of the Corinth Rift, the Perachora Peninsula, and the Kaparelli area (lower left inset in Figure 2). We then clipped the composite DEM using drainage areas of the Peloponnesian rivers that discharge into the gulf and the three largest reversed rivers that are now endorheic basins, that is, Feneos, Stymfalia, and Skotini. We manually delineated these areas of internal drainage to avoid the inaccuracies of automatic methods.

\subsection{Stacked Swaths}

Stacked swaths are a large number of parallel swath profiles projected together perpendicularly to their trends into a "stack." Swath profiles that are stacked together into a pile highlight areas of the topography that have similar slopes andover all morphology in a direction perpendicular to the point of view, i.e. areas of topographic coherence "in depth" in the projection direction. Stacked swaths allow the study of the continuity of morphological features in three-dimensions and over large regions (Armijo et al., 2015). We use stacked swaths to portray up to $50 \mathrm{~km}$ of across-strike footwall topography that includes the three largest reversed river catchments. Using our composite DEM of the rift margin, we derive parallel swath profiles that average topography, and stack them orthogonally to the strike of the Main fault system (taken as $\mathrm{N} 105^{\circ} \mathrm{E}$ ), plotting them looking WNW as hairlines. We use 300 swath profiles to portray the main rift sector that is $\sim 60 \mathrm{~km}$ long along the rift margin strike (Figure 4a) and 100 swath profiles for two $\sim 30-\mathrm{km}$-long sectors that cover the eastern and western half of the main sector (Figures $4 \mathrm{~b}$ and $4 \mathrm{c}$ ). The width of each individual swath is defined dynamically by dividing the total width of the DEM by the number of swath profiles along the projection direction. This leads to swaths with widths of $\sim 200 \mathrm{~m}$ for the plot in Figure 4a and swaths with widths of $\sim 300 \mathrm{~m}$ for the plots in Figures $4 \mathrm{~b}$ and $4 \mathrm{c}$.

\subsection{Footwall Relief}

The mountain front relief of an uplifting extensional footwall results from long-term uplift, and thus slip of its bounding fault. Range front relief shows the cumulative fault displacement and can be used to infer the dimensions of the active fault and its history of growth and linkage (e.g., Dawers \& Anders, 1995; Gupta \& Scholz, 2000). We approximate the range front relief using the footwall relief. Footwall relief is an underestimation of range front relief since erosion occurring in the footwall is not taken into account. We define and calculate footwall relief along the rift margin in a similar fashion to Whittaker and Walker (2015). We consider footwall relief as the absolute difference in elevation, measured vertically, from the trace of the fault to the first prominent topographic break in slope in the footwall topography, which represents the crest of frontal relief. The crest of frontal relief can be confidently followed along the rift margin in our composite DEM or Google Earth. Moreover, crest of frontal relief is set by first-order triangular facets in the footwall (see Figure 11b and section 7.6.2 in Fernández-Blanco et al. (2019) for a detailed description of the triangular facets along the rift margin).

We defined a polygon in the DEM that covers the main fault sector, extending from the fault trace inland for $\sim 21 \mathrm{~km}$ inland in a perpendicular direction to each fault sector (Figure 2, top right inset). This polygon covers the first topographic break of slope, which in the rift margin is at distances of $<20 \mathrm{~km}$, often $\sim 15 \mathrm{~km}$, inland perpendicularly from the fault trace strike. This polygon removes topography farther away from the fault and facilitates recognition of the first break of slope in the footwall. We calculate footwall relief along the "main" rift sector using this polygon. To determine the position of the first topographic break of slope, we use $\sim 20$-m-wide swaths of average topography that are orthogonal to the fault trace and that we derive every $20 \mathrm{~m}$ along its strike. These swaths profiles running across-footwall mark the first relevant inflection point in the frontal relief and provide us with a continuous trace of it in the along-footwall 

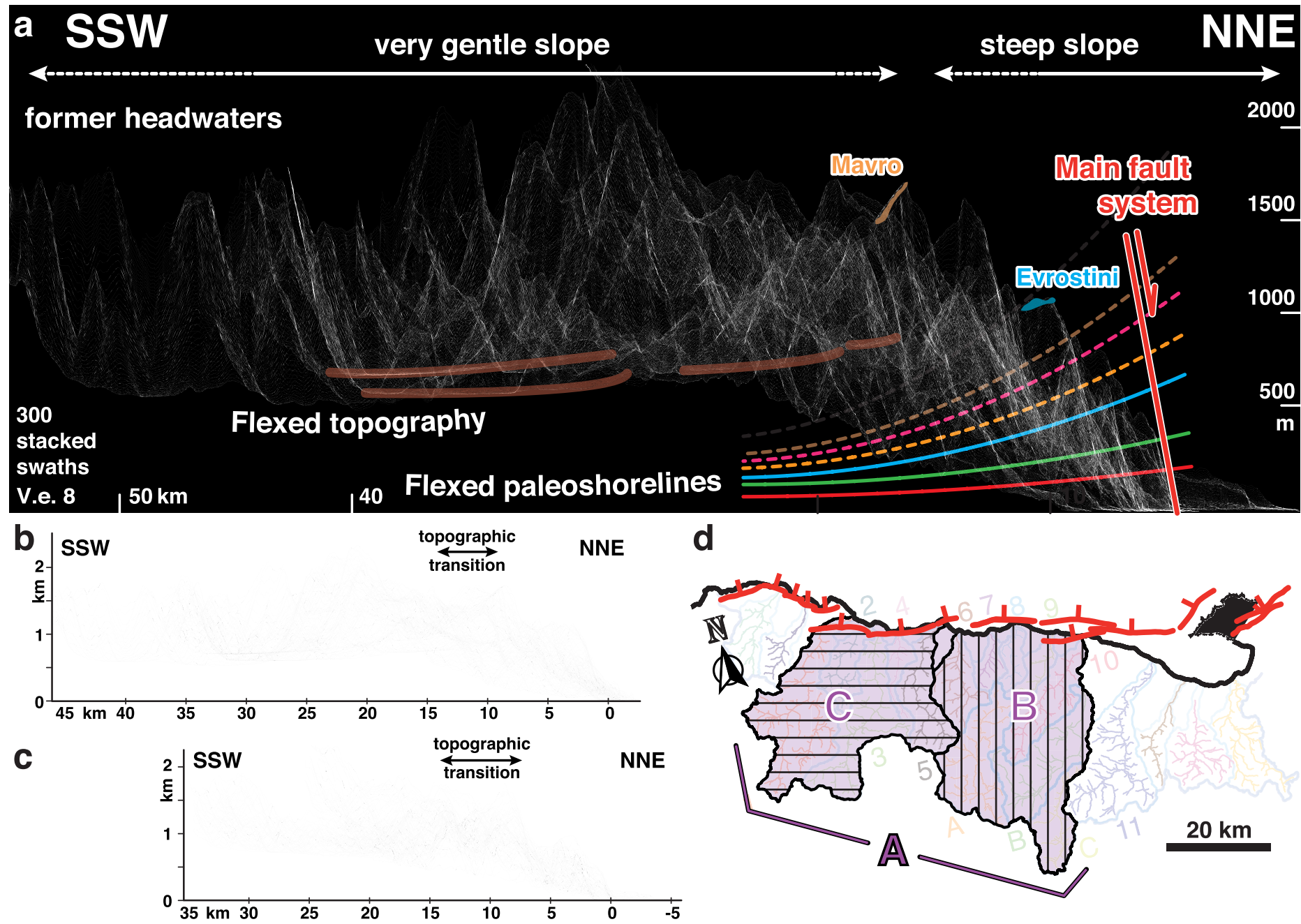

d

Figure 4. Across-footwall topography. (a) View of topography perpendicular to the bounding fault strike along the entire main sector (defined in section 4), looking WNW. The DEM area covered is shown in purple (as "A" in (d)). The view covers $\sim 60 \mathrm{~km}$ along the south rift flank and results from projecting 300 swath profiles perpendicularly to their strike, which is orthogonal to the Main fault system $\left(\mathrm{N} 105^{\circ} \mathrm{E}\right)$. Swath profiles are exaggerated $\sim 8$ times in the vertical. Areas of large topographic coherency along the footwall lead to whiter sectors. Thicker semitransparent red lines highlight gently south dipping sectors of coherent-in-depth topography that are consistent with the lower topographic heights along the footwall (flexed topography), and with the best fit quadratic curves derived from the paleoshorelines in Figure 3, in different colors (flexed paleoshorelines). The end of these sectors that is closer to the fault coincides with a topography change to steep slopes to the north. This topographic inflection is capped by the perched Gilbert-type deltas of Mavro and Evrostini. (b) View of topography perpendicular to the bounding fault strike for the eastern half of the main sector (shown in vertical stripes in D), constructed as described in A. This view uses 100 topographic swaths with a vertical exaggeration of $~ 5.5$. (c) View of topography perpendicular to the bounding fault strike for the western half of the main sector (area of horizontal stripes in D), constructed as described in A. This view uses 100 topographic swaths with a vertical exaggeration of $~ 5.5$. (d) Index map, with an indication of footwall area covered by each of the three stacked swaths.

direction. We trace this along-footwall continuous line of footwall relief manually and estimate associated uncertainties that we attach graphically.

We consider that the calculation of footwall relief has no associated errors in the horizontal direction, given that we used swaths of average topography that are $\sim 20 \mathrm{~m}$ wide at $20-\mathrm{m}$ intervals on a DEM that has $20 \mathrm{~m}$ of horizontal resolution. We estimated the vertical uncertainty considering two factors: confidence in the accurate mapping of the fault trace and the discrepancy between fault strike and chosen direction of projection. The master fault can be confidently mapped in the west of the main sector, where uncertainties associated with the position of the fault trace are minimal. Eastward, the position of the master fault is more imprecise as the fault lays underwater and its trace can only be mapped 
with less accuracy. We estimate a maximum vertical uncertainty of $\sim 250 \mathrm{~m}$ for the eastern main sector due to this effect, in combination with the unconstrained growth behavior of the footwall relief underwater. We further attribute a maximum estimated uncertainty of $\pm 50 \mathrm{~m}$ to the discrepancy between our chosen projection plane and the fault strike toward the eastern areas of the main sector. We consider the equivalent uncertainty negligible in the western main sector.

\subsection{Longitudinal River Profiles}

First-order clues on the evolution of normal fault systems can be deduced from local convexities (knickpoints or knickzones) in the longitudinal profiles of footwall rivers. For example, a change in rock uplift rate will lead to the upstream migration of a knickpoint as a kinematic wave, and the river channel will steepen in the wake of the passing knickpoint (Rosenbloom \& Anderson, 1994). The knickpoint acts as a mobile boundary between a former portion of the stream unaware of a change in uplift rate and an adjusted or adjusting downstream reach (e.g., Snyder et al., 2000; Whipple \& Tucker, 1999). We used Topotoolbox 2.0 (Schwanghart \& Scherler, 2014) to extract the river profiles and $\chi$ Profiler package (Gallen \& Wegmann, 2017) for river profile analysis. Fluvial channels were derived for areas draining $\geq 10^{6} \mathrm{~m}^{2}$, that is, where fluvial processes dominate over debris-flow processes (e.g., Stock \& Dietrich 2003), and smoothed with a 500-m moving window average in order to remove local effects outside the scope of this contribution.

We performed specific corrections to derive the river geometry of the longitudinal profiles of the three reversed, endorheic river catchments. We locate the lowest point of the longest stream and set it as an artificial outlet by creating a sink. We then clip the DEM using the areas that drain to the sink from the north and from the south. We perform the stream flow calculation of Topotoolbox 2.0 (Schwanghart \& Scherler, 2014) to extract the longitudinal river profiles of the river streams draining each clipped area. Finally, we oriented the outcome of the river profiles according to their general flow direction, that is, one flowing northward and one southward. The resulting longitudinal profile was oriented to match the flow direction in the longitudinal profiles of gulf-draining rivers.

\subsection{Height of the Principal Inflections (Knickzones and Windgaps)}

River profile knickpoints have vertical rates of propagation that are a function of the change in the rate of footwall uplift (Attal et al., 2008; Crosby \& Whipple, 2006; Whittaker et al., 2008; Wobus et al., 2006). Assuming uniform climate and substrate properties, knickpoints resulting from a temporal change in uplift rate will propagate vertically at the same rate (Niemann et al., 2001). Along normal faults, which typically show variable rates of uplift along strike, the relative height of knickpoints would be a function of such differential along-strike uplift, i.e. tectonic knickpoints at higher positions may be linked to faster fault throw rates; Whittaker et al., 2008; Whittaker \& Walker, 2015). Knickpoint height depends on the relative throw rate increase along the driving fault strike (e.g., Whittaker \& Walker, 2015), and can thus be used as a proxy for the magnitude of along-footwall uplift that ultimately relates to the distribution of slip along the fault.

In this contribution, we analyze collectively gulf-draining rivers and river systems formed by two formerly connected rivers that are at present disconnected and bounded by a windgap. We collectively name knickzones and windgaps as principal inflections. In our analysis, we collectively use the height of the main knickzones in river longitudinal profiles of trunks of rivers draining the gulf and also the height of the windgaps of formerly connected rivers, approximated as the drainage divide above the highest point of the behaved rivers.

\subsection{Normalized Steepness Index $\left(k_{s n}\right)$ Below the Principal Inflections}

Researchers have demonstrated that there is a functional relationship between rock uplift rate or erosion rate and river channel steepness normalized upstream by contributing drainage area, which suggests that river channel steepness can be used as a proxy for relative rate of uplift or erosion (DiBiase et al., 2010; Gallen \& Wegmann, 2017; Ouimet et al., 2009; Snyder et al., 2000). These empirical studies are supported by quasi-physical models of river incision that imply that bedrock river incision is related to the upstream drainage area, a proxy for discharge, and local channel slope (Howard, 1994; Tucker \& Whipple, 2002; Whipple \& Tucker, 1999). The most general of these models is the detachment-limited stream power incision 
model, which, when combined with mass-conservation, describes the change in river bed elevation over time as follows:

$$
\frac{d z}{d t}=U-E=U-K A^{m} S^{n}
$$

where $d z / d t$ is the change in elevation of the channel bed with time; $U$ is the rock uplift rate relative to a fixed base level; $E$ is the river erosion; $A$ is the upstream drainage area; $S$ is the local channel slope; $K$ is a dimensional coefficient that incorporates variables dependent on incision process, substrate, climate, and hydrology of erosion (e.g., Whipple, 2004); and $m$ and $n$ are the positive constants that depend on basin hydrology, channel geometry, and erosion processes (Howard, 1994; Whipple, 2004; Whipple \& Tucker, 1999). Assuming steady-state conditions where rock uplift rate and erosion rate are equal, local channel slope can be cast as a function as

$$
S=(U / K)^{1 / n} A^{-(m / n)}
$$

Equation (2) has the same form as Flint's (1974) law, which describes the equilibrium geometry of a longitudinal river profile as a power law function of upstream contributing drainage area through the channel parameters of the steepness index and concavity index. The steepness index is proportional to the ratio of rock uplift to substrate erodibility and the concavity index is equal to the ratio of $m$ to $n$ (Kirby \& Whipple, 2001; Snyder et al., 2000).

The river channel concavity, defined as $\theta$ or $\mathrm{m} / \mathrm{n}$, is theoretically independent of rock uplift rate or erosion rate but will strongly impact the steepness index of the river. In an effort to remove the influence of channel concavity on the steepness index many researchers use a fixed reference concavity index, defined as $\theta(\mathrm{m} / \mathrm{n})$, to derive a normalized steepness index, $k_{s n}$. From theory, the concavity index $(\theta)$ should vary between $\sim 0.3$ and 0.7 , and many empirical studies find a value of $\sim 0.45$ for most river profiles near equilibrium or graded conditions (Kirby \& Whipple, 2012; Snyder et al., 2000; Wobus et al., 2006). Thus, most researchers use a reference concavity of 0.45 , as is used in this study, to calculate the normalized steepness index and assess relative patterns of rock uplift in space and time.

Traditionally, $k_{s n}$ is calculated by a linear regression of $\log S$ and $\log A$ (Kirby \& Whipple, 2012); however, Perron and Royden (2013) recognized that this approach introduces unwanted noise in the data and they propose the integral or $\chi$ method of river profile analysis instead, which we use here. The $\chi$ analysis relies on a transformation of the horizontal coordinate for a river profile, from distance to $\chi$, where $\chi$ is an integral quantity with units of length. Separating variables in equation ((2)), assuming $U$ and $K$ are spatially invariant, and integrating yields

$$
z(x)=z\left(x_{b}\right)+\left(\frac{U}{K}\right)^{\frac{1}{n}} \int_{x_{b}}^{x} \frac{d x}{A(x)^{m / n}}
$$

where $\mathrm{z}$ is elevation and $x_{b}$ is base level. The trailing term on the right-hand side of the equation is unitless. Therefore, a reference drainage area $A_{o}$ is introduced such that

$$
z(x)=z\left(x_{b}\right)+\left(\frac{U}{K A_{o}^{m}}\right)^{\frac{1}{n}} \chi
$$

where

$$
\chi=\int_{x_{b}}^{x}\left(\frac{A_{o}}{A(x)}\right)^{m / n}
$$

Equation (4) is convenient because it has the form of a line where $z$ is the dependent variable, $\chi$ is the independent variable, $z\left(x_{b}\right)$ is the $y$ intercept, and $\left(\frac{U}{K A_{o}^{m}}\right)^{\frac{1}{n}}$ is the slope. Plots of $\chi$ and $z$ are referred to as $\chi$ plots. It is 
important to recognize that when $A_{o}$ is assumed to be 1 , the slope in a $\chi$ plot is the same as $k_{s n}$; thus, it is best practice to always use an $A_{o}$ equal to 1 to standardize $\chi$ plots (e.g., Gallen $\&$ Wegmann, 2017).

Being a metric sensitive to the rock uplift rate (Snyder et al., 2000), we calculate the values of the $k_{s n}$ of river streams below the main inflection as proxies for the magnitude of along-footwall uplift rate and thus the distribution of slip rate along-strike in the active fault system, providing that erodibility and climatic variations are minor with regards to variations in rock uplift (Kirby \& Whipple, 2001).

\section{Landscape Record of Flexural Uplift}

We analyse the geometry of morphotectonic features and footwall metrics along the main rift sector and characterize the long-term activity of the bounding fault.

\subsection{Across-Footwall Topography}

We analyze the geometry of the across-footwall topography (Figure 4) by means of swath topographic profiles stacked orthogonally to the active fault. Swath profiles stacked across the footwall show that the topography has a consistent geometry throughout the $\sim 60 \mathrm{~km}$ long main rift segment (Figure $4 \mathrm{a}$ ). The topography across the footwall shows a stark transition, from a steep coastal topography up to $\sim 1.5 \mathrm{~km}$ in elevation at $\sim 15 \mathrm{~km}$ from the rift-bounding fault, into a flat topography sloping southward $<300$ m over horizontal distances of $>35 \mathrm{~km}$ (Figure $4 \mathrm{a}$ ). Areas of topographic coherence along strike (superimposed white lines) gently dip south at the base of the flat inland topography. They have a curvature and wavelength (semitransparent red lines) that correlate with the flexural uplift signal derived from paleoshoreline angles of marine terraces that are located immediately eastward (cf. Figures 3 and $4 \mathrm{a}$ ). These areas are tilted south over tens of kilometers, despite laying at the bottom of horizontalized fluvial channels and internally drained basins, where deposition tens to level the landscape and partially mask the back-tilt (Figure 4).

The across-footwall topography in the east (Figure $4 \mathrm{~b}$ ) shows a sharper transition between the steep coastal slopes and gentle inland slopes than across-footwall topography in the west of the main rift sector (Figure 4c). Similarly, the along-footwall topographic change seems to be located closer to the fault and at higher elevations in the eastern than in the western region of the footwall (cf. Figures $4 \mathrm{~b}$ and $4 \mathrm{c}$ ). The coherence of topography (see section 4.2) is remarkable along the footwall in the direction perpendicular to the main fault (Figure 4a), and larger for the eastern main sector of the rift margin, where topography tilts markedly southward (cf. Figures $4 \mathrm{~b}$ and $4 \mathrm{c}$ ). The above suggests that the topography of the main rift sector responds to flexure as a whole in a similar manner than the Late Pleistocene marine terraces. This implies that the flexural uplift signal controlling the latter is sustained on the long term $\left(\sim 10^{6}\right.$ years $)$ and dominates, ad minimum, the main sector of the rift margin.

\subsection{Across-Footwall River Profiles}

We analyze the geometry of the longitudinal profiles of footwall river networks located across the rift margin, and roughly orthogonal to the active fault (Figure 5 and Supporting Information S1). The profile geometry of footwall rivers orthogonal to the fault depart from theoretical rivers in equilibrium that have smooth-graded, concave-upward profiles (Figure 5a). All river profiles exhibit a principal inflection, defined as either a convex-up knickzone or a windgap, marking a stark morphologic transition at $~ 15-$ $25 \mathrm{~km}$ from the active fault (Figure 5a). This principal inflection separates either (i) steep lower reaches from broad, low-gradient upland reaches that have different degrees of back-tilt along the extensional footwall or (ii) steep gulf-draining rivers from endorheic basins that record drainage inversion (Figures 2 and 5). Overall, the principal inflection is located closer to the fault in the rift center, and farther away from it along strike (see white-grey contact for main river catchments in eastern and western main sector in Figure 5a). Similarly, the degree of back tilt in low-gradient inland reaches decreases along the rift margin strike away from the rift center, dominated by short steep gulf-draining rivers and reversed drainages (Figures 2, 5b, and 5c). Given that most rivers steepen in response to enhanced rates of rock uplift (Snyder et al., 2000) and that the principal inflection mirrors the topography seemingly, we infer that large knickzones and windgaps are of common origin and result from a rapid increase in uplift rate along the full length of the master fault system. 

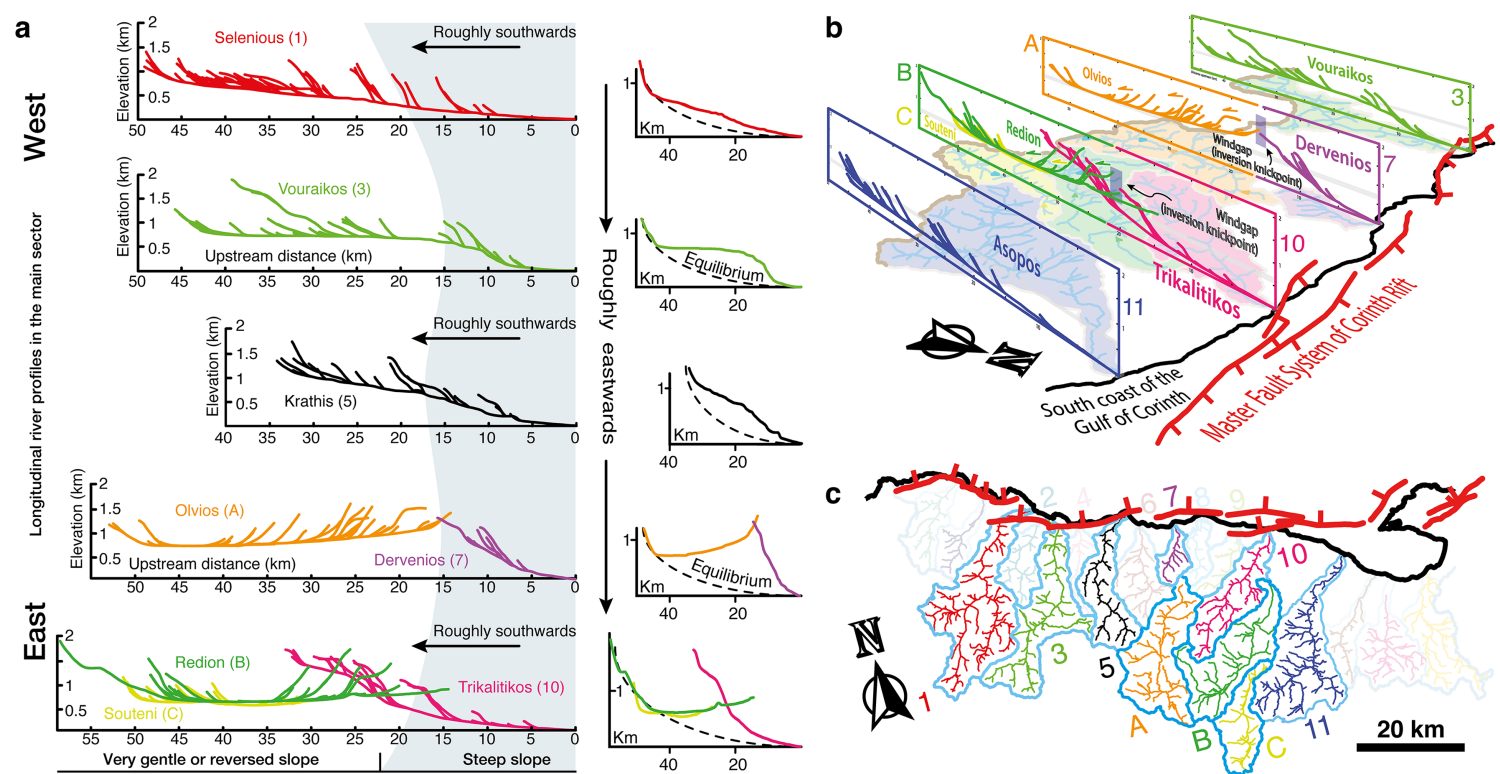

Figure 5. Across-footwall river profile topography. (a) River longitudinal profiles along the rift margin. River long profiles of five out of the six largest drainages in the rift margin, at the same scale and with their outlets aligned vertically, from the west (at the top) to the east (at the bottom). In the rift center, we plot reversed and beheaded rivers together. Plots to the right show the main trunks of the same rivers and the outline of their theoretical smooth-graded profiles of equilibrium. (b) The 3-D view of longitudinal profiles of river catchments and the plain view of their drainage areas, with regard to the master fault system. The view covers $\sim 60 \mathrm{~km}$ along, and $50 \mathrm{~km}$ across, the Main fault system. Note the prominent size of the reversed catchments in the center of the rift, both in upstream drainage longitudinal profiles and plain views. (c) Index map, with an indication of footwall river drainages used in A and B. Gulf-draining rivers are indicated with numbers: $1=$ Selenious, $3=$ Vouraikos, $5=$ Krathis, $7=$ Dervenios, $10=$ Trikalitikos, $11=$ Asopos. Reversed-flow river basins, now endorheic, are indicated with letters: $\mathrm{A}=$ Olvios, $\mathrm{B}=$ Redion, $\mathrm{C}=$ Souteni.

\subsection{Along-Footwall Relief}

We explore the geometry of the fault footwall relief along the rift margin strike (Figure 6), approximated by the difference in elevation from the active fault to the first major break-of-slope in the footwall topography. The along-footwall gradient in footwall relief (Figure 6) varies in a systematic manner along the main rift sector as an asymmetric parabola of wavelength $>60 \mathrm{~km}$. The parabola decays from the rift center, which is located at $\sim 35 \mathrm{~km}$ from the west end of the main rift sector (Figure 6). The footwall relief decays parabolically from its maximum height of $\sim 2.5 \mathrm{~km}$ in the rift center to $\sim 1.25$ and $\sim 0.75 \mathrm{~km}$ in the east and west end of the main rift sector, respectively. The current footwall relief is therefore consistent with a pattern of fault slip that defines a cumulative parabolic displacement, which length correlates to that of the margin. This pattern is expected for long-term activity $\left(\sim 10^{6}\right.$ years $)$ along a single, high-angle fault system of rift margin scale.

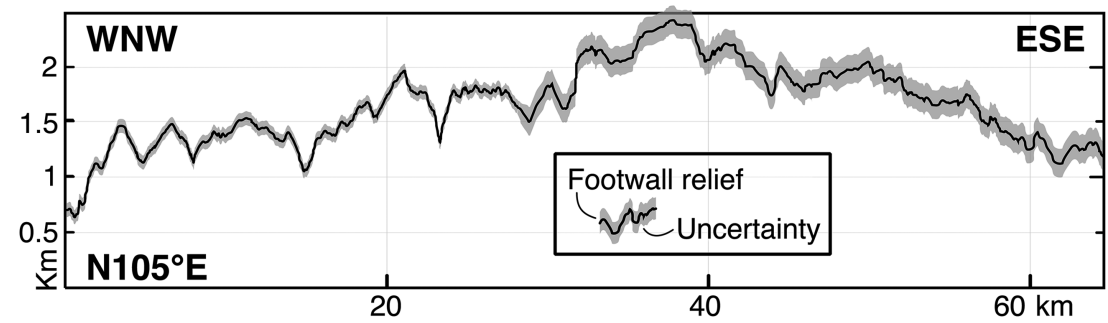

Figure 6. Footwall relief projected along the fault strike. Distribution of footwall relief along master fault strike. Footwall relief is the height difference between the principal inflection and the master fault trace, measured vertically. Uncertainty is estimated from fault mapping precision and the relative departure between fault strike and projection strike. See details in section 4.3 . 


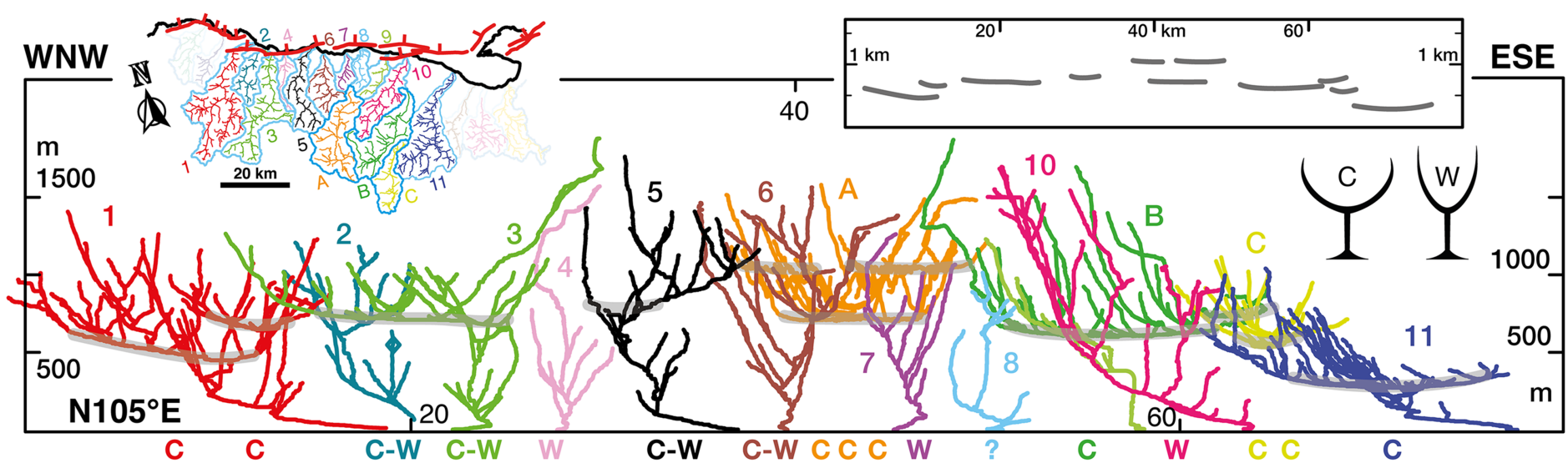

Figure 7. River profiles projected along the fault strike. (a) Distribution of river longitudinal profiles along master fault strike. River longitudinal profiles projected along the fault strike in the main sector $\left(\mathrm{N} 105^{\circ} \mathrm{E}\right)$, with 8 times vertical exaggeration. The morphology of the river valleys is indicated below the profile with the letters: (C) cognac-glass valleys, (W) wine-glass valleys, $(\mathrm{C}-\mathrm{W})$ cognac-glass valleys in upland reaches and wine-glass valleys in the lowland reaches. River reaches that drain low-relief areas at the bottom of the cup of cognac-glass valleys are highlighted with thick semitransparent grey lines. Numbers and letters correspond to those indicated in the index map in the top left inset. Numbers and letters correspond to those indicated in the index map in the top left inset. This inset shows gulfflowing rivers with numbers and reversed-flow drainages with letters as $1=$ Selenious, $2=$ Kerinitis, $3=$ Vouraikos, $4=$ Ladopotamos, $5=$ Krathis, $6=$ Krios, $7=$ Dervenios, $8=$ Skoupeiko, $9=$ Fonissa, $10=$ Trikalitikos, and $11=$ Asopos, $\mathrm{A}=$ Olvios, $\mathrm{B}=$ Redion, $\mathrm{C}=$ Souteni. The top right inset shows the elevation of areas with low-relief streams.

\subsection{Along-Footwall River Profiles}

We explore the geometry of the footwall along its strike by projecting river networks and reversed basins toward the fault (Figure 7). River profiles projected toward the fault show geometries that also respond to a parabolic pattern along the same footwall sector (Figure 7). The upland reaches of the largest drainages have low-gradient streams that occupy relevant along-footwall distances (see rivers 1, 3, and 11 in Figure 7), a morphology that resembles that of the reversed river drainages (A, B, and C in Figure 7). The elevation of these flat regions marks a morphological transition in drainage flow patterns, also for rivers where such flat regions are not evident (see rivers 2, 4, 5, 6, 8, 9, and 10 in Figure 7). This cognac-glass valley morphology contrasts with the wine-glass valleys observed in shorter rivers, and in the lower reaches of some of the longer drainages (see 2, 3, 4, 5, and 7 in Figure 7). The elevation of the flat regions at the bottom of cognac-glass valleys vary consistently and in agreement with a parabola much like that defined by the footwall relief (cf. Figure 6 and top right inset in Figure 7). Again, this parabolic pattern defines the cumulative fault slip, and thus fault surface uplift, expected for sustained activity $\left(\sim 10^{6}\right.$ years $)$ along a composite, kinematically coherent, high-angle fault at rift scale.

\subsection{Along-Footwall Elevation of Principal Inflections and $\boldsymbol{k}_{\boldsymbol{s} n}$ Values for River Streams Below Each of Them}

The elevation of the principal inflection (knickzones and windgaps) is highest in the center of the modern rift and decays asymmetrically but systematically along the rift margin (Figure 8a). The principal inflections have heights that correlate with the along-footwall parabolic pattern shown by the footwall relief (Figure 6), at lower elevations. The elevation of principal inflections is maximum for rivers in the rift center, with values commonly above the $1,000 \mathrm{~m}$ (from 4 to 10 with the exception of 8 at around $\sim 800 \mathrm{~m}$; Figures $8 \mathrm{a}-8 \mathrm{~d}$ ). Principal inflections are at lower elevations in rivers toward the tips the main rift sector, with heights that range between $\sim 650$ and $\sim 250 \mathrm{~m}$ ( 1 to 3 and 11; Figures $8 \mathrm{a}-8 \mathrm{~d}$ ). The pattern of lateral gradients in $k_{s n}$ of the downstream reaches is less clean (Figure $8 \mathrm{~b}$ ). Either $k_{s n}$ of the downstream reaches portrays a parabolic decay from its center and River 3 (Vouraikos) is an outlier, or it shows a roughly linear increase toward River 3 and then decays abruptly. Given the parabolic geometry of fault slip derived from other proxies, we consider the former more plausible than the latter. If our inference is correct, then the distribution of footwall metrics sensitive to relative uplift rates record along-footwall variations in flexural uplift that appears consistent with slip along a single, composite fault system acting at rift-margin scale. If not, only the knickpoint elevation shows the signal of slip along a rift-scale fault, and the $k_{s n}$ values show a different signal that is 

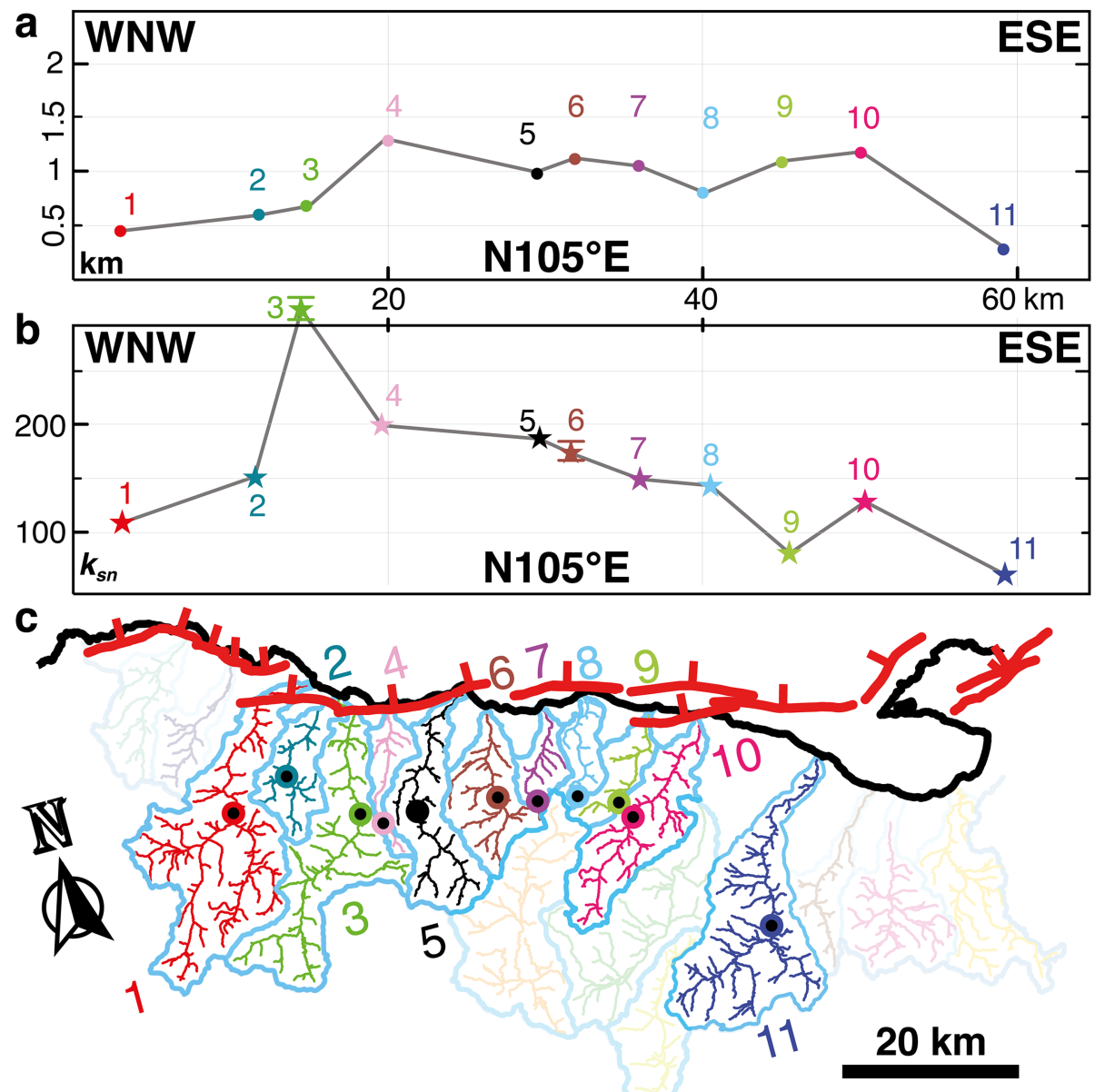

\begin{tabular}{|c|c|c|c|c|}
\hline River (\#) & $X$ coord & Y coord & Height (m) & $k_{s n}$ below \\
\hline Selinous (1) & 588486 & 4218540 & 438 & 110.5 \\
\hline Kerinitis (2) & 595446 & 4222140 & 585 & 147.9 \\
\hline Vouraikos (3) & 602126 & 4214800 & 661 & 331.4 \\
\hline Ladopotamos (4) & 604166 & 4214100 & 1264 & 199.3 \\
\hline Kratis (5) & 611666 & 4206960 & 970 & 183.5 \\
\hline Krios (6) & 616446 & 4207780 & 1116 & 172.8 \\
\hline Devrenios (7) & 621186 & 4212840 & 1054 & 145.5 \\
\hline Skoupeiko (8) & 627266 & 4212280 & 810 & 137.7 \\
\hline Fonissa (9) & 627146 & 4208960 & 1084 & 81.5 \\
\hline Trikalitikos (10) & 627066 & 4201740 & 1175 & 132.4 \\
\hline Assopos (11) & 644386 & 4190120 & 265 & 63.1 \\
\hline
\end{tabular}

Figure 8. Along-strike projection of the principal inflections and $k_{s n}$ values downstream of each principal inflection. (a) Height of the principal inflection and (b) normalized steepness index $\left(k_{s n}\right)$ of river reaches below each inflection, both projected at the river outlets orthogonally to the main fault system $\left(\mathrm{N} 105^{\circ} \mathrm{E}\right)$. Error bars are smaller than the symbols in both plots in all cases except for rivers 3 and 6 in (b). (c) Index map, with an indication of footwall river drainages used in $\mathrm{A}$ and $\mathrm{B}$, and the location of the principal inflection in map view. Numbers show the gulf-draining rivers of $1=$ Selenious, $2=$ Kerinitis, $3=$ Vouraikos, $4=$ Ladopotamos, $5=$ Krathis, $6=$ Krios, $7=$ Dervenios, $8=$ Skoupeiko, $9=$ Fonissa, $10=$ Trikalitikos, and $11=$ Asopos. The principal inflection is indicated with circles. (d) Location and elevation of the main inflections and $k_{s n}$ values of streams below them.

perhaps related to the known gradient in modern GPS velocities with an increase of $\sim 0.5 \mathrm{~mm} /$ year westward (e.g., Avallone et al., 2004).

A finer along-footwall characterization of flexure is precluded by the effects of river location relative to bounding fault trace, recent drainage reversals, changes in drainage area, and/or local faulting. For 
example, the $k_{s n}$ values for Vouraikos and Fonissa rivers ( 3 and 9 in Figure $8 \mathrm{~b}$ ) are two outliers that we interpret as the result of a recent increase in uplift rate magnitude by fault linkage and a recent increase in drainage area, respectively. However, whereas the latter interpretation seems plausible, the former is only tentative, as the river crosses a continuous trace in the East Helike Fault. Another significant effect is the drainage reorganization and large river reversals that have occurred in some rivers east of River 6 (Figure 2). We expect larger $k_{s n}$ values for equilibrated river catchments that recently lost drainage area in this region (beheaded rivers 6 to 10; Figure 8c). Larger uncertainties exist for the same area east of River 6, as the fault increases in distance from river outlets. Finally, local effects may affect the Asopos River (11 in Figures $8 \mathrm{a}$ and $8 \mathrm{c}$ ) since it lays at the tip of the fault sector considered, and where the fault is underwater and away from the river outlet. Either or both these facts may lead to the low elevations of the river principal inflection, precluding a clean interpretation. Therefore, while the along-footwall parabolic distributions (Figures 6, 7, and 8a) are consistent with maximum cumulative footwall flexural uplift and uplift rate in the rift center, we attribute larger confidence to the finite geometry of the western half of the parabola.

\section{Discussion}

Our geomorphologic evidence novelly outlines the flexural uplift geometry resulting from early intracontinental rifting in the Corinth Rift. The continental lithosphere of the uplifting margin coherently up-bends across the rift $(>50 \mathrm{~km})$ and has a parabolic decay along the rift $(>60 \mathrm{~km})$ throughout faulting $\left(\sim 10^{6}\right.$ years $)$. This flexural pattern at the scale of the rift margin dictates the geometry of the footwall topography and its river profiles, and the magnitude of geomorphic proxies for uplift, uplift rate, and fault displacement.

\subsection{Implications for the Corinth Rift}

The landscape of the Corinth Rift southern margin evolves in response to flexure (Figures 1a and 9). Footwall topography and river drainages show morphologies (Figures 4-8) that are consistent with a cumulative signal of flexural uplift that is spatially coherent over most of the rift: an exponential increase toward the fault and a parabolic decay from the rift center along its strike (Figure 9). The across-footwall flexure signal is unequivocal in the topography for $>60 \mathrm{~km}$ along the footwall, with the back-tilt of the inland regions for $30 \mathrm{~km}$ or more across the footwall (Figure 4). Rivers adjust to flexure by steepening their lower reaches and forcing a marked back-tilt in their upper reaches that decays along strike from the area of maximum uplift (Figure 5). In fact, the across-footwall back-tilt is larger than portrayed (Figures 4 and 5), given that the low-gradient inland areas have low erosive power and are prone to sedimentary deposition that tends to level the landscape morphology.

Conspicuous drainage reversals landward of gulf-flowing beheaded drainages occur in the rift center, where the topographic expression of flexure is most prominent (Figures 4 and 5). Both the location of drainage reversals and the different degrees of landward tilting in the upstream reaches correlate positively with the height of footwall relief and the main inflections of river profile measured from the fault (Figures 58a). Collectively, the above suggest that maximum slip rates occur at the rift center and lead to flexural uplift rates that are also the largest at the rift center (Figure 9). This agrees with previous research that suggested larger uplift in the rift center (e.g., Armijo et al., 1996; Dufaure, 1975; Pirazzoli et al., 2004). We infer that large flexural uplift rates exceeding river incision capabilities result in drainage reversal of inland reaches (Figure 9). This is supported by numerical models (Cowie et al., 2006).

The flexural model apposite at rift scale (Figure 9) yields novel inferences on rift mechanics. The distributions of flexural uplift and slip rates are consistent with well-known relationships for single fault systems (Figures 3-8; e.g., Cowie \& Scholz, 1992; Dawers et al., 1993; Densmore et al., 2004; Roberts \& Michetti, 2004), thus defining a single, high-angle fault system kinematically linked at rift scale (Figures 1a and 8; Fernández-Blanco et al., 2019). Inherited relief resulting from distributed faulting (e.g., Gawthorpe et al., 1994; Goldsworthy \& Jackson, 2001) in relation to the Aegean Sea back-arc extension (e.g., Brun \& Sokoutis, 2010; Jolivet et al., 2013) is limited, and in stark contrast with the modern short-wavelength, high-amplitude rift relief (Figure 4). This was observed by early works in the area (e.g., Ori, 1989), and together with the morphological similarity between footwall topography and river profiles (cf. Figures 4 and 5) supports a young and fast growth of the modern rift margin (e.g., Fernández-Blanco et al., 2019). These observations, in turn, suggest a subsidiary role for regional uplift (e.g., Turner et al., 2010) and paleorelief (e.g., Ghisetti \& Vezzani, 2005) in the modern rift evolution (Figure 9). 
a1 Early stage
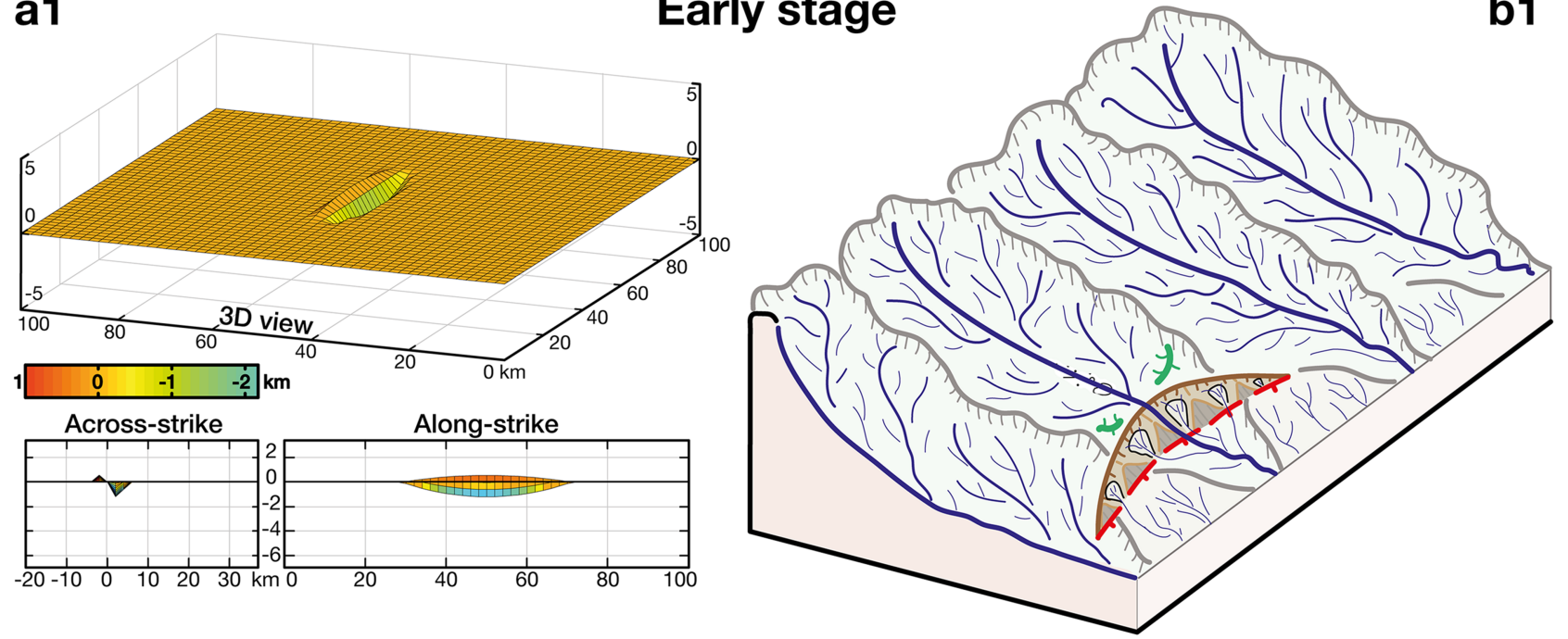

a2

Middle stage

b2
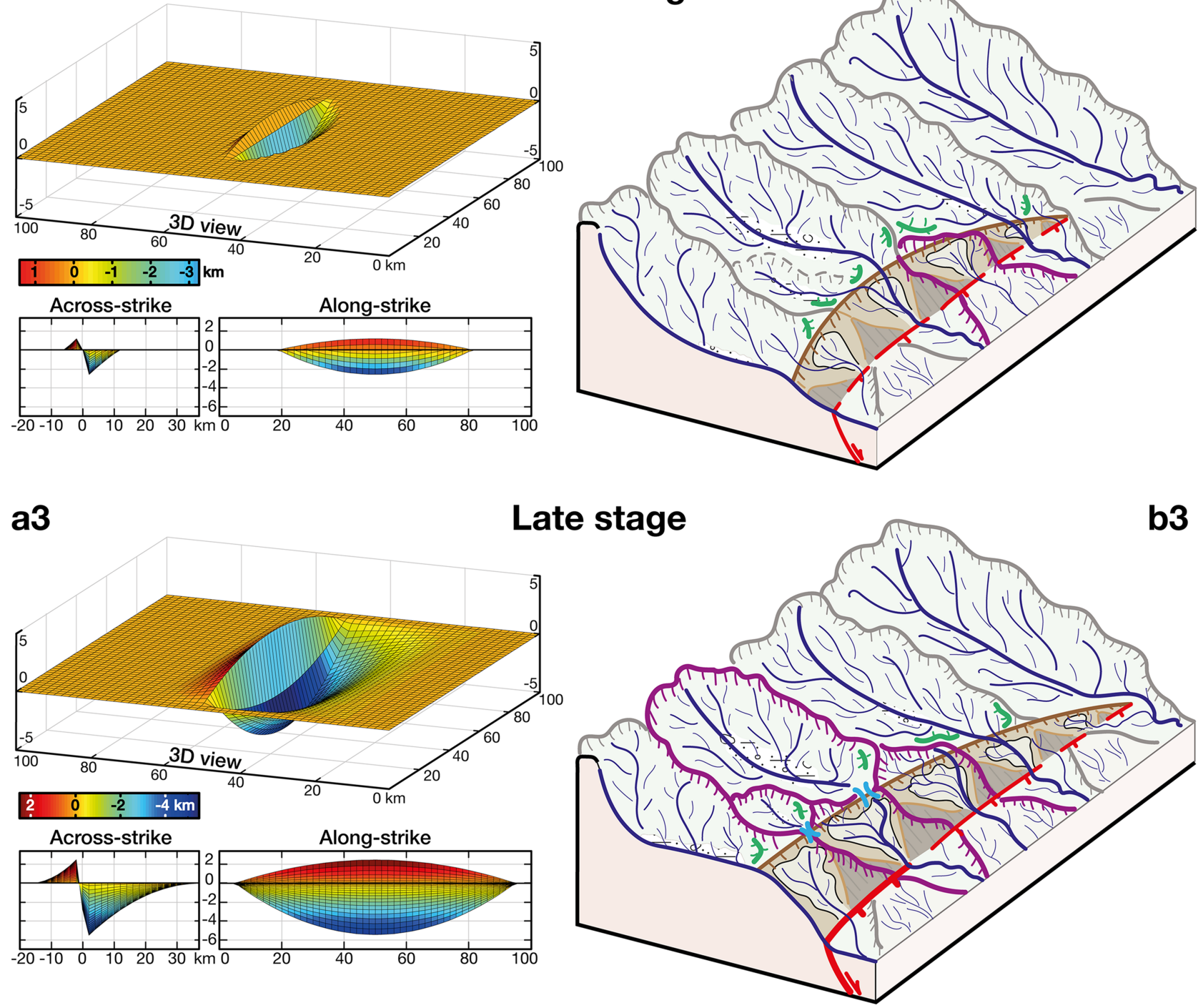
The remarkable consistency of the cumulative elastic flexure signal observed in the across-footwall topography along the rift margin and its coherency with its shorter-term signal set by Pleistocene marine terraces (Figure 4) implies highly localized strain along the master fault system since its onset (Figure 9). This agrees with previous studies on rift bounding-fault localization (e.g., Roberts et al., 2009). Moreover, modeling studies show that long-term, large-scale flexural footwall uplift as the one reported here (Figure 9) requires repeated coseismic slip on localized high-angle faults that reach at least the brittle-ductile transition (Bell et al., 2017; De Gelder et al., 2019; King et al., 1988), and an isostatic elastic response of the whole crust (e.g., King \& Ellis, 1990). Collectively, the above implies the master fault transects the crust to the brittleductile transition in a lithosphere with large strength and consistent both spatially, at rift scale $(>50 \mathrm{~km})$, and temporally, throughout faulting ( $10^{6}$ years $)$.

\subsection{Implications for Early Continental Rifting}

Geometric characterizations of flexure, similar to that presented here (Figure 9), hold the potential to deepen our understanding of the relationships between landscape evolution, elastic flexure, and faulting in actively extending regions, such as the Basin and Range, the East African, and Baikal rifts or Tibet. For example, the prime information on rheology, mechanics, or dynamics derived from the geometry of topography in areas of upflexed continental lithosphere (Armijo et al., 1996; Brown \& Phillips, 1999; De Gelder et al., 2019; Masek et al., 1994; Owens, 1983; ter Voorde et al., 1998; Zandt \& Owens, 1980) is limited by the time span and spatial extent of the markers used. Contrarily, our approach provides constraints on the along-footwall geometry, extent, and coherency of the flexural uplift signal (Figures 4-9). In turn, these constrain relate with the long-term lithospheric strength at the rift scale, the length and downdip geometry of the accommodating fault(s), and the crustal-scale strain localization. We hope that modeling studies further explore these relationships taking advantage of our MatLab script (Script S2 in Supporting Information S1), that provides the geometry of flexure as shown in a1 to a3 in Figure 9.

Our work illustrates that the evolving elastic flexure associated with regional-scale faults (tens of kilometers) during long-term $\left(10^{4}-10^{6}\right.$ years) extension of continental lithosphere is recorded in their uplifting landscapes. The landscape records the surface uplift that is associated with a signal of rock uplift that decays exponentially away from the border fault and is sustained temporally since its onset. At the time of fault activity initiation, surface uplift and rock uplift are comparable. As the river drainage system adapts to the new boundary condition imposed by uplift in the active fault, the signals of net surface uplift and rock uplift dissociate. Near the fault, where the signal of rock uplift is maximum, steep rivers carve the landscape and reduce surface uplift to near zero in river channels. Away from the fault trace, the signal of rock uplift decays and the nearly flat upstream river reaches decrease the river erosive capabilities. As a result, rock uplift and surface uplift can be assumed to be comparable in these inland regions. This is observed in the morphology of these upper reaches (Figure 7). However, the upper reaches preserve relief that is associated with their former morphology, especially near their headwaters, and the drainages may be tilted headwards, as in the rift center. Therefore, once a new fault rifts a continental region, the single place of the landscape where the rock uplift signal led by the active fault coincides with the pattern of surface uplift is in the main inflections of footwall rivers.

\footnotetext{
Figure 9. The 3-D geometry of flexural uplift by continental rifting and its effect on landscapes. Evolutionary block diagrams that schematically show (a) the 3-D geometry of flexure in relation to extensional faulting in continents and (b) its effects on a sector of a fluvial landscape. (a) Block models showing the geometry of flexure in 3-D, and its associated across- and along-footwall views. Each block diagram has a horizontal grid $100 \mathrm{~km}$ wide in both directions with squares of $2 \times 2$ $\mathrm{km}$, and extends $10 \mathrm{~km}$ in the vertical direction, that is exaggerated 3 times. The 3-D flexural geometry couples the across-footwall exponential flexure defined by De Gelder et al. (2019) and a quadratic curve that fits the along-footwall parabolic geometry of the fault footwall derived here (see Figure 6). We obtain the hanging-wall flexure geometry using the same geometric constraints and an assumed uplift-to-subsidence ratio of 1:2.2, that is, the average between calculated values for the rift; 1:1.2-2.4 (De Gelder et al., 2019) and 1:2-3.2 (McNeill \& Collier, 2004). The fault locates at the center of the grid and has a maximum surficial length of (a1) $30 \mathrm{~km}$, (a2) $60 \mathrm{~km}$, and (a3) $90 \mathrm{~km}$, but the fault trace and fault plane are not shown. Along-strike panels show a composite view of the appearance of the footwall (for the panel sector above $0 \mathrm{~m}$ ) and the hanging-wall (for the panel sector below $0 \mathrm{~m}$ ) that look orthogonally toward the fault in both cases. The initial and intermediate growth stages (a1 and a2) are scaled versions of a3 and their flexural geometry is unconstrained. (b) Block models of a fluvial landscape evolving in relation to the growth of the crustal normal fault and its associated lithospheric flexure in (a). The hanging wall flexural subsidence and the location of sea level are not represented, for simplicity, and the frontal view locates on a river trunk. The fault is in red and the footwall relief is shown in brown colors, with darker tones for the triangular facets and lighter tones for small river drainages formed on the fault relief. Rivers are in blue and their drainage divides in light grey for inherited drainages and in purple for fault-formed drainages. Thick green lines represent areas with streams that drain in reverse direction and wind gaps are shown with thick blue lines.
} 
The processes of flexural uplift and highly localized strain shown for the Corinth Rift may be masked in other rifts or at later stages by ambiguous geomorphological evidence and/or denudation. Prominent reversals of river catchments that exist in older and low-extending rifts and individual grabens, as the East African Rift and South Tibet (Armijo et al., 1986; Doornkamp \& Temple, 1966), can be explained if elastic flexure and localized strain occurred at the early stages of intracontinental rifting. Given that the landscape record of flexural uplift and highly-localized strain in Corinth is unmatched worldwide, we suggest that these processes are intrinsic to the earliest stages of continental rifting. The generalization of elastic flexure processes to intracontinental extension areas of any age or extension rate implies that the process of rifting is highly disruptive and strain localized.

\section{Conclusion}

We provide a finer characterization of the flexural geometry produced by intracontinental rifting, and its associated flexural uplift signal, during fault activity $\left(10^{4}-10^{6}\right.$ years), and virtually in three-dimensions (tens of kilometers). We explore the geomorphic expression of flexure throughout the landscape of the southern margin of the Corinth Rift using new and conventional representations of standard approaches aimed at highlighting simple geometrical relationships between geomorphic elements in extensional footwalls and their active normal faults. We novelly define the evolving, combined effect of progressive flexure and uplift at the scale of the rift margin, thereby characterizing the geometry of flexure at the rift scale. The signal of flexure is highly coherent in space and time, implying highly localized strain along a crustal-scale, highangle normal fault affecting continental lithosphere with long-term strength that reaches the base of the seismogenic layer or deeper. Considering this record of flexure is unique worldwide, we generalize flexural uplift and strain localization as intrinsic processes of early intracontinental rifting in nature.

\section{Acknowledgments}

We thank the editorial work of Laurent Jolivet and Marcelo Farias. We thank Carole Petit for the suggestions that improved the final version of the manuscript and the detailed comments of an anonymous reviewer. We are in debt to Patience Cowie and Sean Gallen for the discussions on earlier versions of the manuscript. We thank Dimitris Papanastassiou and Spyros Liakopoulos for the many discussions during the IPGP annual field course "Living Faults." D.F.B. is also in debt with Utsav Mannu for his MatLab script (see Figure 9a and Script S2 in Supporting Information S1)) and thanks editions in the final text by James Norcliffe. DEM data used for our analysis can be downloaded from the repository (https://figshare.com/articles/DEM_ Corinth_Southern_Margin_20m_res_/ 10013141). The DEM is derived from ALOS AW3D30 DSM (ALOS) ASTER GDEM V2 (ASTER) and SPOT5 DEM data merged and resampled at 20-m resolution. Original SPOT5 DEM data are under restrictive academic license and thus not open for distribution. Procedures to reproduce the analyses are described in the text. The research leading to this study has received funding from the People Programme (Marie Curie Actions) of the European Union's Seventh Framework Programme under the ITN project ALErT (grant FP7-PEOPLE-2013-ITN 607996) and by the ISIS program of the CNES. This study contributes to the IdEx Université de Paris ANR-18IDEX-0001. This is IPGP contribution 4080.

\section{References}

Armijo, R., Lacassin, R., Coudurier-Curveur, A., \& Carrizo, D. (2015). Coupled tectonic evolution of Andean orogeny and global climate. Earth-Science Reviews, 143, 1-35.

Armijo, R., Lyon-Caen, H., \& Papanastassiou, D. (1991). A possible normal-fault rupture for the 464 BC Sparta earthquake. Nature, 351(6322), 137-139.

Armijo, R., Meyer, B., King, G. C. P., Rigo, A., \& Papanastassiou, D. (1996). Quaternary evolution of the Corinth Rift and its implications for the Late Cenozoic evolution of the Aegean. Geophysical Journal International, 126(1), 11-53.

Armijo, R., Tapponnier, P., Mercier, J. L., \& Han, T.-L. (1986). Quaternary extension in southern Tibet: Field observations and tectonic implications. Journal of Geophysical Research, 91(B14), 13,803-13,872.

Attal, M., Tucker, G. E., Whittaker, A. C., Cowie, P. A., \& Roberts, G. P. (2008). Modeling fluvial incision and transient landscape evolution: Influence of dynamic channel adjustment. Journal of Geophysical Research, 113, F02010. https://doi.org/10.1029/2007JF000893

Avallone, A., Briole, P., Agatza-Balodimou, A. M., Billiris, H., Charade, O., Mitsakaki, C., et al. (2004). Analysis of eleven years of deformation measured by GPS in the Corinth Rift Laboratory area. Comptes Rendus Geoscience, 336(4-5), 301-311.

Bell, R. E., Duclaux, G., Nixon, C. W., Gawthorpe, R. L., \& McNeill, L. C. (2017). High-angle, not low-angle, normal faults dominate early rift extension in the Corinth Rift, central Greece. Geology, 46(2), 115-118. https://doi.org/10.1130/G39560.1

Bernard, P., Lyon-Caen, H., Briole, P., Deschamps, A., Boudin, F., Makropoulos, K., et al. (2006). Seismicity, deformation and seismic hazard in the western rift of Corinth: New insights from the Corinth Rift Laboratory (CRL). Tectonophysics, 426(1-2), 7-30. https://doi. org/10.1016/j.tecto.2006.02.012

Boulton, S. J., \& Whittaker, A. C. (2009). Quantifying the slip rates, spatial distribution and evolution of active normal faults from geomorphic analysis: Field examples from an oblique-extensional graben, southern Turkey. Geomorphology, 104(3-4), 299-316.

Brown, C. D., \& Phillips, R. J. (1999). Flexural rift flank uplift at the Rio Grande rift, New Mexico. Tectonics, $18(6), 1275-1291$.

Brun, J.-P., \& Sokoutis, D. (2010). 45 m.y. of Aegean crust and mantle flow driven by trench retreat. Geology, 38(9), 815-818.

Buck, W. R. (1993). Effect of lithospheric thickness on the formation of high- and low-angle normal faults. Geology, 21(10), 933-936.

Bürgmann, R., Pollard, D. D., \& Martel, S. J. (1994). Slip distributions on faults: effects of stress gradients, inelastic deformation, heterogeneous host-rock stiffness, and fault interaction. Journal of Structural Geology, 16(12), 1675-1690.

Charalampakis, M., Lykousis, V., Sakellariou, D., Papatheodorou, G., \& Ferentinos, G. (2014). The tectono-sedimentary evolution of the Lechaion Gulf, the south eastern branch of the Corinth graben, Greece. Marine Geology, 351, 58-75.

Corti, G., Molin, P., Sembroni, A., Bastow, I. D., \& Keir, D. (2018). Control of pre-rift lithospheric structure on the architecture and evolution of continental rifts: Insights from the Main Ethiopian Rift, East Africa. Tectonics, 37, 477-496. https://doi.org/10.1002/ 2017TC004799

Cowie, P. A., Attal, M., Tucker, G. E., Whittaker, A. C., Naylor, M., Ganas, A., \& Roberts, G. P. (2006). Investigating the surface process response to fault interaction and linkage using a numerical modelling approach. Basin Research, 18(3), 231-266.

Cowie, P. A., \& Scholz, C. H. (1992). Displacement-length scaling relationship for faults: data synthesis and discussion. Journal of Structural Geology, 14(10), 1149-1156.

Crosby, B. T., \& Whipple, K. X. (2006). Knickpoint initiation and distribution within fluvial networks: 236 waterfalls in the Waipaoa River, North Island, New Zealand. Geomorphology, 82(1), 16-38.

Dawers, N. H., \& Anders, M. H. (1995). Displacement-length scaling and fault linkage. Journal of Structural Geology, 17(5), 607-614.

Dawers, N. H., Anders, M. H., \& Scholz, C. H. (1993). Growth of normal faults: Displacement-length scaling. Geology, 21(12), 1107-1110. 
de Gelder, G., Fernández-Blanco, D., Melnick, D., Duclaux, G., Bell, R. E., Jara-Muñoz, J., et al. (2019). Lithospheric flexure and rheology determined by climate cycle markers in the Corinth Rift. Scientific Reports, 9(1), 4260.

Demoulin, A., Beckers, A., \& Hubert-Ferrari, A. (2015). Patterns of Quaternary uplift of the Corinth rift southern border (N Peloponnese, Greece) revealed by fluvial landscape morphometry. Geomorphology, 246, 188-204.

Densmore, A. L., Dawers, N. H., Gupta, S., \& Guidon, R. (2005). What sets topographic relief in extensional footwalls? Geology, 33(6), 453-456.

Densmore, A. L., Dawers, N. H., Gupta, S., Guidon, R., \& Goldin, T. (2004). Footwall topographic development during continental extension. Journal of Geophysical Research, 109, F03001. https://doi.org/10.1029/2003JF000115

DiBiase, R. A., Whipple, K. X., Heimsath, A. M., \& Ouimet, W. B. (2010). Landscape form and millennial erosion rates in the San Gabriel Mountains, CA. Earth and Planetary Science Letters, 289(1), 134-144.

Doornkamp, J. C., \& Temple, P. H. (1966). Surface, Drainage and Tectonic Instability in Part of Southern Uganda. The Geographical Journal, 132(2), 238-252.

Doutsos, T., \& Piper, D. J. W. (1990). Listric faulting, sedimentation, and morphological evolution of the Quaternary eastern Corinth rift, Greece: First stages of continental rifting. Geological Society of America Bulletin, 102(6), 812-829.

Dufaure, J.-J. (1975). Le relief du Péloponèse (Thése Lettres). Université Paris IV.

Dufaure, J.-J. (1977). Néotectonique et morphogenèse dans une péninsule méditerranéenne: Le Péloponnèse. Revue de Géographie Physique et de Géologie Dynamique, 19, 27-58.

Fernández-Blanco, D., de Gelder, G., Lacassin, R., \& Armijo, R. (2019). A new crustal fault formed the modern Corinth Rift. Earth-Science Reviews.

Flint, J. J. (1974). Stream gradient as a function of order, magnitude, and discharge. Water Resources Research, 10(5), 969-973.

Ford, M., Hemelsdaël, R., Mancini, M., \& Palyvos, N. (2016). Rift migration and lateral propagation: evolution of normal faults and sediment-routing systems of the western Corinth rift (Greece). Geological Society, London, Special Publications, 439. https://doi.org/ $10.1144 / \mathrm{SP} 439.15$

Ford, M., Rohais, S., Williams, E. A., Bourlange, S., Jousselin, D., Backert, N., \& Malartre, F. (2012). Tectono-sedimentary evolution of the western Corinth rift (Central Greece). Basin Research, 25, 1-23.

Forsyth, D. W. (1992). Finite extension and low-angle normal faulting. Geology, 20(1), 27-30.

Gallen, S. F., \& Wegmann, K. W. (2017). River profile response to normal fault growth and linkage: An example from the Hellenic forearc of south-central Crete, Greece. Earth Surface Dynamics, 5(1), 161.

Gawthorpe, R., Fraser, A., \& Collier, R. (1994). Sequence stratigraphy in active extensional basins: implications for the interpretation of ancient basin-fills. Marine and Petroleum Geology, 11(6), 642-658.

Gawthorpe, R. L., Leeder, M. R., Kranis, H., Skourtsos, E., Andrews, J. E., Henstra, G. A., et al. (2017). Tectono-sedimentary evolution of the Plio-Pleistocene Corinth rift, Greece. Basin Research, 30(3), 448-479. https://doi.org/10.1111/bre.12260

Ghisetti, F., \& Vezzani, L. (2005). Inherited structural controls on normal fault architecture in the Gulf of Corinth (Greece). Tectonics, 24, TC4016. https://doi.org/10.1029/2004TC001696

Goldsworthy, M., \& Jackson, J. (2001). Migration of activity within normal fault systems: examples from the Quaternary of mainland Greece. Journal of Structural Geology, 23, 489-506.

Goren, L., Fox, M., \& Willett, S. D. (2014). Tectonics from fluvial topography using formal linear inversion: Theory and applications to the Inyo Mountains, California. Journal of Geophysical Research: Earth Surface, 119, 1651-1681. https://doi.org/10.1002/2014JF003079

Gupta, A., \& Scholz, C. H. (2000). A model of normal fault interaction based on observations and theory. Journal of Structural Geology, 22(7), 865-879.

Hemelsdaël, R., \& Ford, M. (2016). Relay zone evolution: a history of repeated fault propagation and linkage, central Corinth rift, Greece. Basin Research, 28(1), 34-56.

Hemelsdaël, R., Ford, M., Malartre, F., \& Gawthorpe, R. (2017). Interaction of an antecedent fluvial system with early normal fault growth: Implications for syn-rift stratigraphy, western Corinth rift (Greece). Sedimentology, 64(7), 1957-1997.

Howard, A. D. (1994). A detachment-limited model of drainage basin evolution. Water Resources Research, 30(7), $2261-2285$.

Jolivet, L., \& Brun, J.-P. (2010). Cenozoic geodynamic evolution of the Aegean. International Journal of Earth Sciences, 99(1), 109-138.

Jolivet, L., Faccenna, C., Huet, B., Labrousse, L., Le Pourhiet, L., Lacombe, O., et al. (2013). Aegean tectonics: Strain localisation, slab tearing and trench retreat. Tectonophysics, 597-598, 1-33.

Kent, E., Boulton, S. J., Whittaker, A. C., Stewart, I. S., \& Cihat Alçiçek, M. (2016). Normal fault growth and linkage in the Gediz (Alaşehir) Graben, Western Turkey, revealed by transient river long-profiles and slope-break knickpoints. Earth Surface Processes and Landforms, 42(5). https://doi.org/10.1002/esp.4049

King, G., \& Ellis, M. (1990). The origin of large local uplift in extensional regions. Nature, 348(6303), 689-693.

King, G. C. P., Stein, R. S., \& Rundle, J. B. (1988). The Growth of Geological Structures by Repeated Earthquakes 1. Conceptual Framework. Journal of Geophysical Research, 93(B11), 13,307-13,318.

Kirby, E., \& Whipple, K. X. (2001). Quantifying differential rock-uplift rates via stream profile analysis. Geology, 29(5), 415-418.

Kirby, E., \& Whipple, K. X. (2012). Expression of active tectonics in erosional landscapes. Journal of Structural Geology, 44, 54-75.

Le Pichon, X., \& Angelier, J. (1981). The Aegean Sea. Philosophical Transactions of the Royal Society of London A: Mathematical. Physical and Engineering Sciences, 300(1454), 357-372.

Manighetti, I., King, G. C. P., Gaudemer, Y., Scholz, C. H., \& Doubre, C. (2001). Slip accumulation and lateral propagation of active normal faults in Afar. Journal of Geophysical Research, 106(B7), 13667-13696.

Masek, J. G., Isacks, B. L., Fielding, E. J., \& Browaeys, J. (1994). Rift flank uplift in Tibet: Evidence for a viscous lower crust. Tectonics, 13(3), 659-667.

McNeill, L. C., \& Collier, R. E. L. (2004). Uplift and slip rates of the eastern Eliki fault segment, Gulf of Corinth, Greece, inferred from Holocene and Pleistocene terraces. Journal of the Geological Society, 161(1), 81-92.

Miller, S. R., Baldwin, S. L., \& Fitzgerald, P. G. (2012). Transient fluvial incision and active surface uplift in the Woodlark Rift of eastern Papua New Guinea. Lithosphere, 4(2). https://doi.org/10.1130/1135.1

Niemann, J. D., Gasparini, N. M., Tucker, G. E., \& Bras, R. L. (2001). A quantitative evaluation of Playfair's law and its use in testing longterm stream erosion models. Earth Surface Processes and Landforms: The Journal of the British Geomorphological Research Group, 26(12), 1317-1332.

Nixon, C. W., McNeill, L. C., Bull, J. M., Bell, R. E., Gawthorpe, R. L., Henstock, T. J., et al. (2016). Rapid spatiotemporal variations in rift structure during development of the Corinth Rift, central Greece. Tectonics, 35, 1225-1248. https://doi.org/10.1002/ 2015 TC004026 
Ori, G. G. (1989). Geologic history of the extensional basin of the Gulf of Corinth (?Miocene-Pleistocene), Greece. Geology, 17(10), 918-921.

Ouimet, W. B., Whipple, K. X., \& Granger, D. E. (2009). Beyond threshold hillslopes: Channel adjustment to base-level fall in tectonically active mountain ranges. Geology, 37(7), 579-582.

Owens, T. J. (1983). Normal faulting and flexure in an elastic-perfectly plastic plate. Tectonophysics, 93(1), 129-150.

Pechlivanidou, S., Cowie, P. A., Duclaux, G., Nixon, C. W., Gawthorpe, R. L., \& Salles, T. (2019). Tipping the balance: Shifts in sediment production in an active rift setting. Geology, 47(3), 259-262.

Perron, J. T., \& Royden, L. (2013). An integral approach to bedrock river profile analysis. Earth Surface Processes and Landforms, 38(6), 570-576.

Petit, C., \& Ebinger, C. (2000). Flexure and mechanical behavior of cratonic lithosphere: Gravity models of the East African and Baikal rifts Journal of Geophysical Research, 105(B8), 19,151-19,162.

Pirazzoli, P. A., Stiros, S. C., Fontugne, M., \& Arnold, M. (2004). Holocene and Quaternary uplift in the central part of the southern coast of the Corinth Gulf (Greece). Marine Geology, 212(1-4), 35-44.

Roberts, G. P., Houghton, S. L., Underwood, C., Papanikolaou, I., Cowie, P. A., van Calsteren, P., et al. (2009). Localization of Quaternary slip rates in an active rift in 105 years: An example from central Greece constrained by 234U-230Th coral dates from uplifted paleoshorelines. Journal of Geophysical Research, 114, B10406. Retrieved from. https://doi.org/10.1029/2008JB005818

Roberts, G. P., \& Michetti, A. M. (2004). Spatial and temporal variations in growth rates along active normal fault systems: an example from The Lazio-Abruzzo Apennines, central Italy. Journal of Structural Geology, 26(2), 339-376.

Roda-Boluda, D. C., \& Whittaker, A. C. (2017). Structural and geomorphological constraints on active normal faulting and landscape evolution in Calabria, Italy. Journal of the Geological Society, 174(4), 701-720.

Rohais, S., Colin, J. P., Suc, J. P., Guillocheau, F., \& Eschard, R. (2007). Age and environmental evolution of the syn-rift fill of the southern coast of the gulf of Corinth (Akrata-Derveni region, Greece). Bulletin de La Société Géologique de France, 178(3), $231-243$.

Rosenbloom, N. A., \& Anderson, R. S. (1994). Hillslope and channel evolution in a marine terraced landscape, Santa Cruz, California. Journal of Geophysical Research, 99(B7), 14,013-14,029.

Schwanghart, W., \& Scherler, D. (2014). TopoToolbox 2 - MATLAB-based software for topographic analysis and modeling in Earth surface sciences. Earth Surface Dynamics, 2(1), 1-7.

Seger, M., \& Alexander, J. (1993). Distribution of Plio-Pleistocene and Modern coarse-grained deltas south of the Gulf of Corinth, Greece. Tectonic Controls and Signatures in Sedimentary Successions, 20, 37-48.

Snyder, N. P., Whipple, K. X., Tucker, G. E., \& Merritts, D. J. (2000). Landscape response to tectonic forcing: Digital elevation model analysis of stream profiles in the Mendocino triple junction region, northern California. GSA Bulletin, 112(8), 1250-1263.

Stein, R. S., King, G. C. P., \& Rundle, J. B. (1988). The growth of geological structures by repeated earthquakes 2 . Field examples of continental dip-slip faults. Journal of Geophysical Research, 93(B11), 13,319-13,331.

Stewart, J. H. (1978). 1: Basin-range structure in western North America: A review. Geological Society of America Memoirs, 152, 1-32.

Stock, J., \& Dietrich, W. E. (2003). Valley incision by debris flows: Evidence of a topographic signature. Water Resources Research, 39(4), 257.

Taylor, B., Weiss, J. R., Goodliffe, A. M., Sachpazi, M., Laigle, M., \& Hirn, A. (2011). The structures, stratigraphy and evolution of the Gulf of Corinth rift, Greece: Structures, stratigraphy and evolution of GoC. Geophysical Journal International, 185(3), 1189-1219.

ter Voorde, M., van Balen, R. T., Bertotti, G., \& Cloetingh, S. A. P. L. (1998). The influence of a stratified rheology on the flexural response of the lithosphere to (un)loading by extensional faulting. Geophysical Journal International, 134(3), 721-735.

Tetreault, J. L., \& Buiter, S. J. H. (2018). The influence of extension rate and crustal rheology on the evolution of passive margins from rifting to break-up. Tectonophysics, 746, 155-172.

Thompson, G. A., \& Parsons, T. (2016). Vertical deformation associated with normal fault systems evolved over coseismic, postseismic, and multiseismic periods. Journal of Geophysical Research: Solid Earth, 121, 2153-2173. https://doi.org/10.1002/ 2015JB012240

Tucker, G. E., \& Whipple, K. X. (2002). Topographic outcomes predicted by stream erosion models: Sensitivity analysis and intermodel comparison. Journal of Geophysical Research, 107(B9), 2179. https://doi.org/10.1029/2001JB000162

Turner, J. A., Leeder, M. R., Andrews, J. E., Rowe, P. J., Van Calsteren, P., \& Thomas, L. (2010). Testing rival tectonic uplift models for the Lechaion Gulf in the Gulf of Corinth rift. Journal of the Geological Society, 167(6), 1237-1250.

Wallace, R. E. (1978). Geometry and rates of change of fault-generated range fronts, north-central Nevada. Journal of Research of the U.S Geological Survey, 6(5), 637-650.

Weissel, J. K., \& Karner, G. D. (1989). Flexural uplift of rift flanks due to mechanical unloading of the lithosphere during extension. Journal of Geophysical Research, 94(B10), 13,919-13,950.

Whipple, K. X. (2004). Bedrock rivers and the geomorphology of active orogens. Annual Review of Earth and Planetary Sciences, 32(1), 151-185.

Whipple, K. X., \& Tucker, G. E. (1999). Dynamics of the stream-power river incision model: Implications for height limits of mountain ranges, landscape response timescales, and research needs. Journal of Geophysical Research, 104(B8), 17,661-17,674.

Whittaker, A. C. (2012). How do landscapes record tectonics and climate? Lithosphere, 4(2), 160-164.

Whittaker, A. C., Attal, M., Cowie, P. A., Tucker, G. E., \& Roberts, G. (2008). Decoding temporal and spatial patterns of fault uplift using transient river long profiles. Geomorphology, 100(3), 506-526.

Whittaker, A. C., \& Walker, A. S. (2015). Geomorphic constraints on fault throw rates and linkage times: Examples from the Northern Gulf of Evia, Greece. Journal of Geophysical Research: Earth Surface, 120, 137-158. https://doi.org/10.1002/2014JF003318

Wobus, C., Whipple, K. X., Kirby, E., Snyder, N., Johnson, J., Spyropolou, K., et al. (2006). Tectonics from topography: Procedures, promise, and pitfalls. Geological Society of America Special Papers, 398, 55-74.

Zandt, B. Y. G., \& Owens, T. J. (1980). Crustal flexure associated with normal faulting and implications for seismicity along the Wasatch front, Utah. Bulletin of the Seismological Society of America, 70(5), 1501-1520.

Zondervan, J. R., Whittaker, A. C., Bell, R. E., Watkins, S. E., Brooke, S. A. S., \& Hann, M. G. (2019). New constraints on bedrock erodibility and landscape response times upstream of an active fault. Geomorphology, 106937, ISSN 0169-555X,. https://doi.org/10.1016/j. geomorph.2019.106937 